\title{
Magma storage, ascent and recharge history prior to the 1991 eruption at Avachinsky Volcano, Kamchatka, Russia: Inferences on the plumbing system geometry
}

\author{
Marco Viccaro a,*, Marisa Giuffrida a ${ }^{a}$, Eugenio Nicotra ${ }^{a}$, Alexey Yu. Ozerov ${ }^{b}$ \\ a Dipartimento di Scienze Biologiche, Geologiche e Ambientali, Università di Catania, Corso Italia 57, I-95129, Catania, Italy \\ ${ }^{\mathrm{b}}$ Russian Academy of Sciences, Institute of Volcanology and Seismology, Piip Boulevard 9, 683006, Petropavlovsk-Kamchatsky, Russia
}

\section{A R T I C L E I N F O}

Article history:

Received 2 September 2011

Accepted 24 January 2012

Available online 3 February 2012

\section{Keywords:}

Kamchatka

Avacha Volcano

Plagioclase texture

Magma chamber

Differentiation

Mixing

\begin{abstract}
A B S T R A C T
Textural and compositional features of plagioclase phenocrysts of the 1991 eruption lavas at Avachinsky Volcano (Kamchatka, Russia) were used to investigate the feeding system processes. Volcanics are porphyritic basaltic andesites and andesites with low-K affinity. A fractionation modeling for both major and trace elements was performed to justify the development of these evolved compositions. The occurrence of other magma chamber processes was verified through high-contrast BSE images and core-to-rim compositional profiles (An\% and $\mathrm{FeO}$ wt.\%) on plagioclase crystals. Textural types include small and large-scale oscillation patterns, disequilibrium textures at the crystal core (patchy zoning, coarse sieve-textures, dissolved cores), disequilibrium textures at the crystal rim (sieve-textures), melt inclusion alignments at the rim. Disequilibrium textures at the cores may testify episodes of destabilization at various decompression rates under water-undersaturated conditions, which suggests different pathways of magma ascent at depth. At shallower, water-saturated conditions, plagioclase crystallization continues in a system not affected by important chemical-physical perturbations (oscillatory zoning develops). Strongly sieve-textured rims, along with An increase at rather constant FeO, are evidence of mixing before the 1991 eruption between a residing magma and a hotter and volatile-richer one. The textural evidence implies that crystals underwent common histories at shallow levels, supporting the existence of a large magma reservoir whose top is at $\sim 5.5 \mathrm{~km}$ of depth. Distinct textures at the outer rims in a hand-size sample are evidence that crystals mix mechanically at very shallow levels, probably in a small reservoir at $\sim 1.8 \mathrm{~km}$ of depth.
\end{abstract}

(C) 2012 Elsevier B.V. All rights reserved.

\section{Introduction}

The bulk rock compositions at volcanoes sited on subduction zones are the result of superimposition of multiple differentiation processes that affect primary magmas after their segregation from the source. These processes include crystal growth with consequent fractionation from the melt, crustal assimilation, changes in the total volatile budget of the system, recharge by physically and chemically distinct magma batches and subsequent mixing. These processes may occur at the same time, thus the definition of their relative role on the final whole rock composition is a hard task. In order to get unambiguous information on the dynamics of natural magmas, several studies have focused their attention on the textural and compositional features recorded by plagioclase crystals of volcanic rocks (e.g., Anderson, 1984; Costa et al., 2003; Davidson and Tepley, 1997; Ginibre et al., 2002a; 2002b; Izbekov et al., 2002; Johannes, 1978; Johannes et al., 1994; Lofgren, 1980; Pearce et al., 1987; Ruprecht and Wörner, 2007; Ruprecht et al., 2008; Shcherbakov et al., 2011; Singer et al., 1995; Smith and Lofgren, 1983; Tsuchiyama, 1985). Indeed, the zoning patterns of plagioclase make

\footnotetext{
* Corresponding author. Tel.: + 390957195741 ; fax: + 390957195760. E-mail address: m.viccaro@unict.it (M. Viccaro).
}

available a record that reflects physical and chemical changes of the melt from which crystals grew. Plagioclase is very common in volcanic rocks and crystallizes over a wide range of magmatic temperatures and pressures. Furthermore, the original compositional zoning can be preserved because the CaAl-NaSi diffusion within the crystal structure is slow (Grove et al., 1984). Analytical approaches based on the investigation of plagioclase textural and compositional characteristics may therefore offer valuable information to understand magma dynamics in the plumbing system before the eruption, especially for volcanic systems scarcely known.

At Avachinsky Volcano (South-eastern Kamchatka, Russia), volcanological and geophysical studies began in '60s (Fedotov et al., 2007; Melekestsev et al., 1994a, 1994b and references therein). The scientific research has shown growing interest especially in the last decade, although the data available on the historical activity, the knowledge of magma dynamics and geometry of the feeding system are still fragmentary. The January 1991 eruption was the first event with an extensive documentation available on the eruptive dynamics and emitted products, which contributed to advance the awareness of the volcano.

Aim of this work is the identification of the feeding system processes and styles of magma ascent before the 1991 eruption at Avachinsky Volcano integrating whole rock geochemical data with the textural and compositional characteristics of plagioclase phenocrysts 
obtained through high-contrast BSE images and core-to-rim compositional profiles. Understanding of the magma recharge regimes from depth, the magma ascent and storage dynamics into the plumbing system of Avachinsky could be useful to evaluate the associated hazard, being the volcano less than $30 \mathrm{~km}$ far from Petropavlovsk, the largest city of Kamchatka.

\section{Geological and volcanological background}

\subsection{Avachinsky Volcano in the framework of Kamchatka geodynamics}

The Kamchatka Peninsula is located on the north-western border of the Pacific Ocean, where the Pacific plate north-westerly dips under the Euro-Asiatic and American plates (Gorbatov et al., 1997; 1999). This area is one of the most active over the world with about 30 active volcanoes and hundreds of monogenic volcanic systems distributed along belts of various age. From $\mathrm{W}$ to $\mathrm{E}$ three major volcanic zones are observed (Fig. 1): the Sredinny Ridge (SR), the Central Kamchatka Depression (CKD) and the Eastern Volcanic Front (EVF). During Late Eocene, the volcanic front was located on the accreted terrains of the SR (Auer et al., 2009; Volynets, 1994 and references therein). The growth of the intra-oceanic domain of the Eastern Kamchatka caused the blocking of the subduction zone with breaking-off and consequent sinking of the subducting slab (Avdeiko et al., 2006; Levin et al., 2002; Volynets, 1994). This caused the eastward migration of the subduction zone to its present location. As a consequence of this tectonic resettlement, the volcanism in the SR gradually decreased (Avdeiko et al., 2006; Volynets, 1994), while in Late Miocene the EVF and CKD started to form and Holocene volcanism was mainly concentrated at these sites (Auer et al., 2009 and references therein).
Avachinsky Volcano (2741 $\mathrm{m}$ a.s.l.) is an active volcano located in the EVF, 200-km-far from the Kurili-Kamchatka trench (Fig.1). Together with Aag, Arik, Kozel'skyi and Koryakskyi volcanoes, it forms the so-called "Avachinsky volcanic group”, a Middle Pleistocene-Holocene ridge crossing from northwest to southeast the southern sector of the EVF (Fig. 1; Masurenkov et al., 1991; Fedotov et al., 2007). These volcanoes are located above a Late Pliocene volcano-tectonic depression, constituted of a strongly dislocated Upper Cretaceous basement covered by Neogene-Quaternary volcanogenic deposits (Fedotov et al., 2007). Avachinsky Volcano has a typical SommaVesuvius structure and is composed of lava and pyroclastic rocks with compositions from basalts to andesites (Zavaritsky, 1977). The volcanic edifice is cut by a horseshoe-shaped caldera formed $\sim 30 \mathrm{ka}$ as a result of a sector collapse (Melekestsev et al., 1994b; Ponomareva et al., 2006). Inside this volcanic structure the active Young Cone is nested (Fig. 2a).

The volcanic activity at Avachinsky started about 60-70 ka (Fedotov et al., 2007), although its Holocene pyroclastic deposits cover the most ancient products. Starting from the Holocene, the volcanic history of Avachinsky Volcano is grouped in two stages (Braitseva et al., 1998; Melekestsev et al., 1989), which are separated by the formation of the Young Cone. The first period $(7.2-3.5 \mathrm{ka})$ was dominated by voluminous Plinian eruptions that produced pumiceous ash-falls and pyroclastic flows with andesitic composition (Braitseva et al., 1997; Braitseva et al., 1998). An increase of the eruption frequency about $3.5 \mathrm{ka}$ ago led to the formation of the Young Cone inside the Late Pleistocene caldera, with magma compositions that shifted to basaltic andesites (Braitseva et al., 1995, 1998; Puzankov et al., 2004). Alternating explosive and effusive eruptions characterized the activity of the Young Cone. Although the historical database shows several lacunas, fourteen eruptive events were recorded since 1737 . The most recent known eruption, although

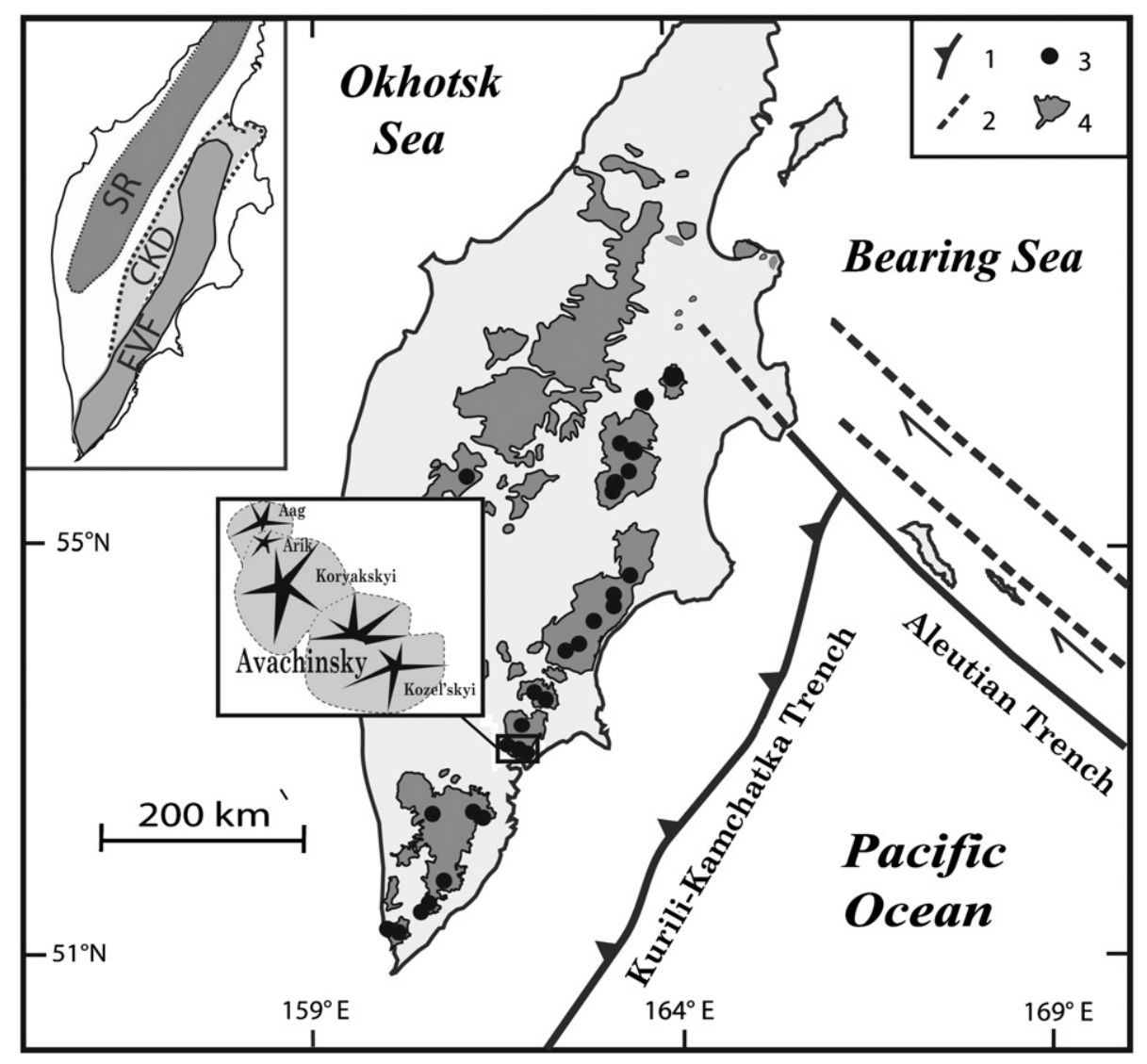

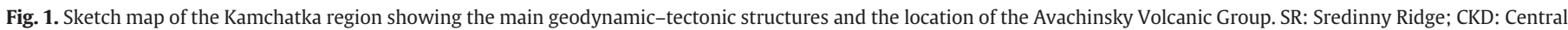

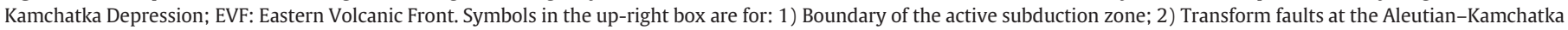
arcs junction; 3) Active volcanic centers; 4) Quaternary volcanic rocks.

Modified from Portnyagin and Manea (2008). 


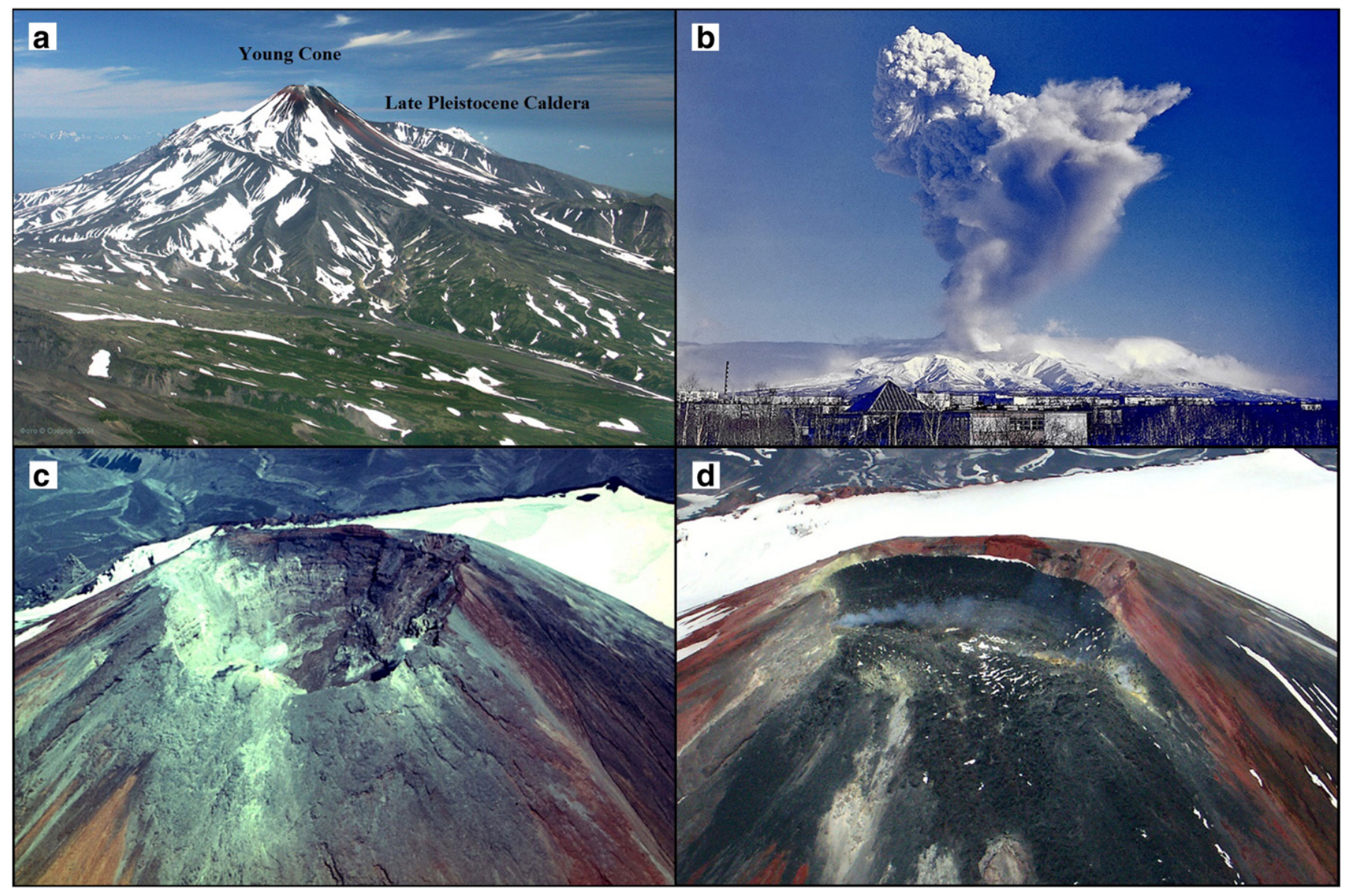

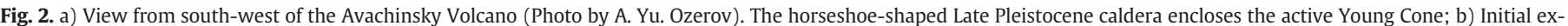

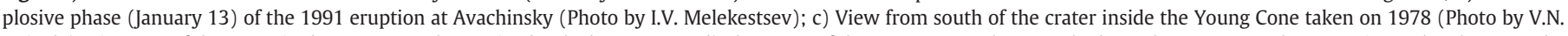

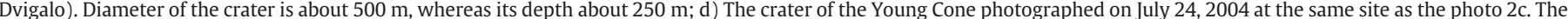

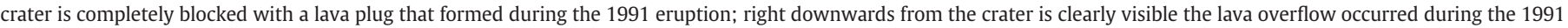
event (Photo by A. Yu. Ozerov).

of small intensity, occurred on 2001. On the basis of tephrostratigraphic studies, two main periods of high eruption frequency were recognized (Melekestsev et al., 1994b): the first between the 1737 and 1827, whereas the second between 1926 and 1945. Lower eruption frequency and scarcer volumes of emitted products followed each of these periods.

The feeding system of Avachinsky Volcano may be constituted by two magma chambers sited at different crustal depths. The shallower reservoir should be located at the boundary between the base of the Young Cone and the floor of the Late Pleistocene caldera (Melekestsev et al., 1994b). The volume of this chamber was estimated $\sim 0.3-$ $0.5 \mathrm{~km}^{3}$ on the basis of the heat loss registered during the 46 years rest before the 1991 eruption (Melekestsev et al., 1994b and references therein). In accordance with geological and geophysical investigations (Fedotov, 1982; Fedotov et al., 2007), the deeper magma reservoir should be located at the boundary between the Upper Cretaceous basement and the Neogene-Quaternary volcanogenic succession. Roof of the magma chamber is thought to be at $\sim 1.5 \mathrm{~km}$ b.s.l., whilst its radius and volume were estimated $5.2 \pm 0.9 \mathrm{~km}$ and $\sim 400 \mathrm{~km}^{3}$ respectively (Fedotov et al., 2007).

\subsection{The January 1991 eruption at Avachinsky}

After 46 years of quiescence, the 1991 eruption started on January 13th without any recorded seismic signal as precursor (Melekestsev et al., 1994b). Although the eruption had a limited duration (only 6 days), it provided the first chance to strengthen the understanding of the volcano through modern methodological approaches. The initial eruptive phase (January 13th) was characterized by explosive episodes during which about $60-70 \%$ of the total emitted products $\left(10-15,000 \mathrm{~m}^{3}\right)$ was constituted by lithics derived from the disruption of the crater floor (Fig. 2b). The removed portion of volcanic edifice was $\sim 10,000 \mathrm{~m}^{3}$. Juvenile materials were vesiculated gray and brown-grayish andesites $\left(\mathrm{SiO}_{2}=56-57 \mathrm{wt} . \%\right.$; Melekestsev et al., 1994b; Ivanov et al., 1996). Effusive activity started on January 14th, with products having generally basaltic andesite compositions (Ivanov et al., 1996; Melekestsev et al., 1994b). Lava flowed inside the crater from a vent located on its south-western sector, filling the 175 -m-deep crater and overflowing then on the southern and south-eastern flanks of the Young Cone (Fig. 2c-d). Lava flow reached, at the end of the eruption, $1896 \mathrm{~m}$ a.s.l. The lava overflows from the crater edge were accompanied by hot debris avalanches that triggered also two lahars; the longest was $5.1 \mathrm{~km}$ far from the crater. At the same time, juvenile tephra fallout from the eruptive column continued. Next to the crater ( 2400 m a.s.l.), the 1991 lava flow is $350-\mathrm{m}$-wide and 20 -m-thick. In this area of the lava field, several lateral flows occurred. The main flow was channeled along a valley on the cone flank, reducing its thickness to $18 \mathrm{~m}$. A maximum thickness of $\sim 30 \mathrm{~m}$ was reached at the front of the flow. On January 23th, the total volume of erupted lavas was $8.4 \times 10^{6} \mathrm{~m}^{3}$. In regard of the proportion of emitted lavas $\left(13 \times 10^{6} \mathrm{~m}^{3}\right)$ and pyroclastic products $\left(0.15-0.20 \times 10^{6} \mathrm{~m}^{3}\right)$, the 1991 eruption can be classified as a smallintensity, effusive event, with an average mass eruption rate estimated as $23 \mathrm{~m}^{3} / \mathrm{s}$ (Melekestsev et al., 1994b). 


\section{Sampling and analytical methods}

A sampling of the lavas emitted during the January 1991 eruption at Avachinsky Volcano was performed during a volcanological field trip on August 2004. Eleven lava samples were collected inside the crater of the Young Cone, in portions of the crater not affected by fumarolic activity. Major element compositions on whole rocks were analyzed at the Dipartimento di Scienze Geologiche of Catania (Italy) by means of a Philips PW2404 WD-XRF on powder pellets correcting the matrix effects. Loss on ignition (L.O.I.) was determined by gravimetric methods. Trace element abundances were determined at the SGS Laboratories of Toronto (Ontario, Canada). Powdered rock samples were fused by Na-peroxide in graphite crucibles and dissolved using dilute $\mathrm{HNO}_{3}$. Fusion process involved the complete dissolution of samples in a molten flux. Trace element analyses were then made by means of a Perkin Elmer ELAN 6100 inductively coupled plasma mass spectrometer. Four calibration runs were performed on international certified reference materials at the beginning and end of the analytical run. Precision is better than 5-7\% for all of the analyzed trace elements.

On selected samples (AVA1, AVA2, AVA4, AVA5, AVA7 and AVA8), six thin-polished sections were made for textural investigations and spot microanalyses on plagioclase crystals and for the characterization of the other mineralogical phases. Rocks were cut along the three main orthogonal directions to minimize the effect of 2D sectioning. Modal abundances of the plagioclase textures were estimated under optical microscope through counting all the crystals with apparent $c$-axis longer than $100 \mu \mathrm{m}$ in each section. Fourteen representative plagioclase crystals were analyzed with a focused beam along core-to-rim profiles with stepsize of 5-7 $\mu \mathrm{m}$. High-contrast back-scattered electron (BSE) images and microanalytical data were obtained at the Dipartimento di Scienze Geologiche of Catania (Italy) using a Tescan Vega-LMU scanning electron microscope equipped with an EDAX Neptune XM4-60 micro-analyzer operating by energy dispersive system characterized by an ultra-thin Be window coupled with an EDAX WDS LEXS (wavelength dispersive low energy X-ray spectrometer) calibrated for light elements. Operating conditions were set at $30 \mathrm{kV}$ accelerating voltage and $\sim 8 \mathrm{nA}$ beam current for obtaining high-contrast BSE images and $20 \mathrm{kV}$ accelerating voltage and $0.2 \mathrm{nA}$ beam current for the analysis of major element abundances. The precision of collected data is better than $3 \%$.

\section{Whole rock geochemistry of the 1991 eruption lavas}

The analyzed volcanic rocks exhibit on a Total Alkali vs. Silica diagram compositions ranging between the basaltic andesite and andesite fields (Fig. 3; Table 1). On the $\mathrm{SiO}_{2}$ vs. $\mathrm{K}_{2} \mathrm{O}$ diagram for subalkaline products, lavas of the 1991 eruption fall in the field of low-K calcalkaline series (Fig. 3). $\mathrm{TiO}_{2}, \mathrm{FeO}_{\text {tot }}, \mathrm{K}_{2} \mathrm{O}$ and $\mathrm{P}_{2} \mathrm{O}_{5}$ show positive correlation with $\mathrm{SiO}_{2}$, reaching the highest values in the sample AVA2. As the degree of differentiation proceeds, $\mathrm{Al}_{2} \mathrm{O}_{3}, \mathrm{MgO}$ and $\mathrm{CaO}$ tend to decrease (Fig. 4). In the sample $\mathrm{AVA} 2, \mathrm{Na}_{2} \mathrm{O}$ shows an anomalous depletion, which could be related to alteration as also evidenced by its L.O.I. value (1.5 wt.\%; Table 1 ). On the whole, the 1991 eruption volcanics are within the range of major element compositions generally observed for other Kamchatka products of similar evolutionary degree (Figs. 3 and 4; Table 1; cf. Erlikh, 1966).

Trace element datasets for the Avachinsky volcanic rocks are rather limited in the accessible literature. In $\mathrm{SiO}_{2}$ vs. trace element diagrams, our samples fall and extend the field defined by other Avachinsky volcanics (Fig. 4; dataset from GEOROC database, http:// georoc.mpch-mainz.gwdg.de). Considering the dataset of the 1991 volcanic rocks, most of trace elements (except $\mathrm{Ni}$ and $\mathrm{Sr}$ ) correlate positively with differentiation index such as $\mathrm{SiO}_{2}$ (Fig. 4; Table 1). The AVA1 basaltic andesite shows higher $\mathrm{Zr}$ concentrations with respect to the other samples of comparable differentiation degree (Table 1), which may be due to alteration. Except AVA1, Eu negative anomalies were observed for the samples AVA2, 7, 8 and $10\left(\mathrm{Eu}_{\mathrm{N}}\right)$ $\mathrm{Eu}^{*}$ between 0.86 and 0.89 ).

\section{Petrographic characteristics of the 1991 eruption lavas}

\subsection{Petrography and mineral chemistry}

Basaltic andesite and andesite of the 1991 eruption are rather similar in their petrographic features. They are porphyritic (Porphyritic Index ranging between 30 and 40 in vol.\%) with phenocrysts of plagioclase ( $50 \%$ of the total phenocryst volume), clinopyroxene ( 25 vol.\%), orthopyroxene ( 20 vol.\%) and opaque oxides ( $~ 5$ vol.\%) immersed in a groundmass with hyalophytic texture. Traces of apatite, generally enclosed in clinopyroxene and plagioclase, complete the mineral assemblage. Microlites of the groundmass are usually plagioclase, clinopyroxene and opaque oxides. Glomerophyric structures occur in all the analyzed samples, and are made up by plagioclase-clinopyroxeneoxides or plagioclase-oxides.

Plagioclase is euhedral, with sizes from a few hundreds of microns up to $\sim 5 \mathrm{~mm}$. Phenocrysts are often twinned and show several types of textures, suggesting complex dynamics during the ascent and storage at crustal levels. Textural and compositional features of plagioclase are better described in the next section. Clinopyroxene is euhedral, pale
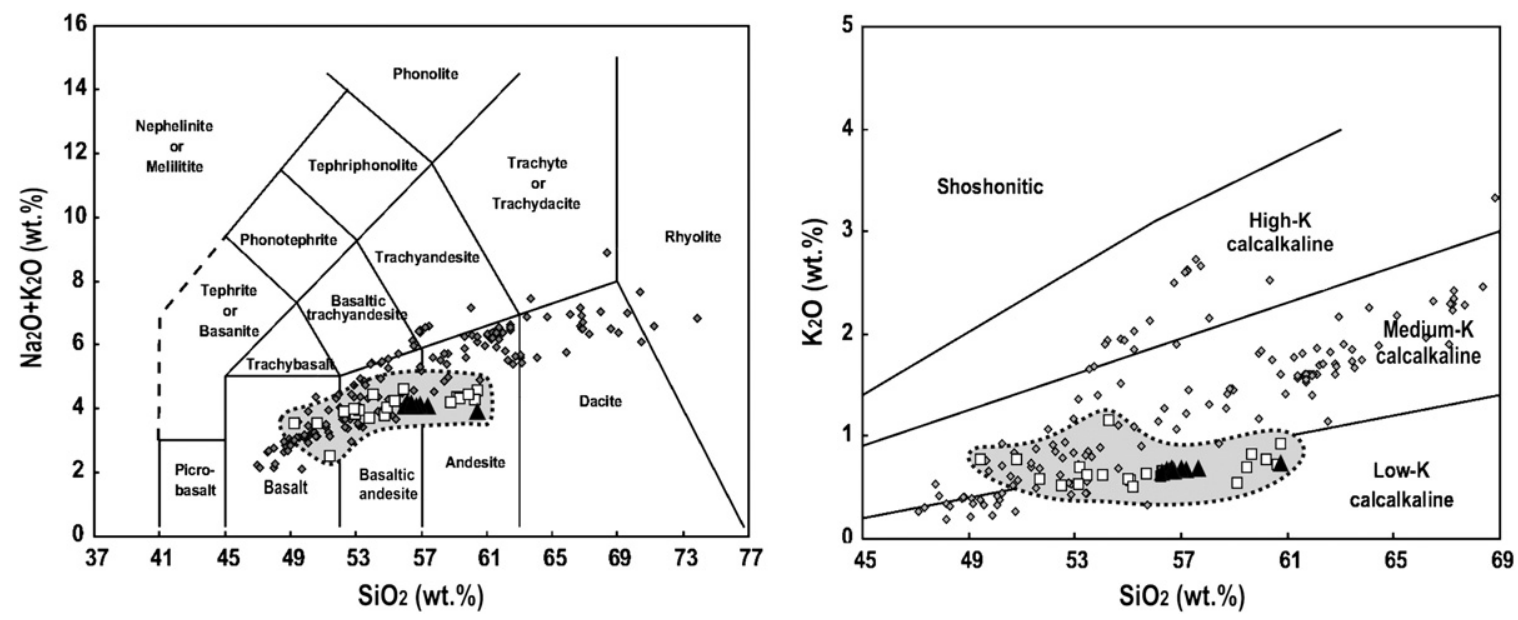

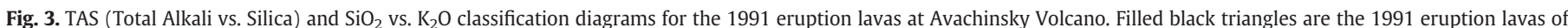

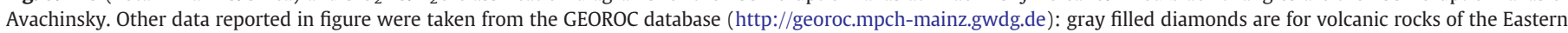

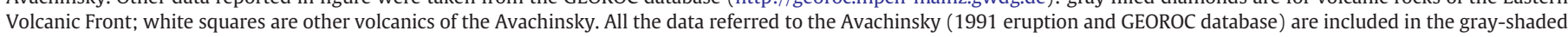
field. 
Table 1

Major and trace element concentrations and ratios of the 1991 eruption lavas at Avachinsky.

\begin{tabular}{|c|c|c|c|c|c|c|c|c|c|c|c|c|}
\hline Sample & AVA1 & AVA2 & AVA3 & AVA4 & AVA5 & AVA6 & AVA7 & AVA8 & AVA9 & AVA10 & AVA11 & Aver BA \\
\hline $\mathrm{SiO}_{2}$ & 56.7 & 60.8 & 56.6 & 56.5 & 56.3 & 56.7 & 57.7 & 57.3 & 57.1 & 56.8 & 56.7 & 53.2 \\
\hline $\mathrm{TiO}_{2}$ & 0.85 & 0.95 & 0.85 & 0.83 & 0.84 & 0.86 & 0.88 & 0.86 & 0.87 & 0.86 & 0.84 & 1.01 \\
\hline $\mathrm{Al}_{2} \mathrm{O}_{3}$ & 17.9 & 14.9 & 18.1 & 18.4 & 18.1 & 18.0 & 17.0 & 17.7 & 17.7 & 17.8 & 18.2 & 19.2 \\
\hline $\mathrm{FeO}_{\text {tot }}$ & 7.59 & 8.01 & 7.63 & 7.35 & 7.58 & 7.60 & 7.77 & 7.60 & 7.68 & 7.58 & 7.39 & 8.51 \\
\hline $\mathrm{MnO}$ & 0.16 & 0.17 & 0.16 & 0.15 & 0.16 & 0.16 & 0.16 & 0.16 & 0.16 & 0.16 & 0.16 & 0.17 \\
\hline $\mathrm{MgO}$ & 3.02 & 2.72 & 3.11 & 2.94 & 3.23 & 3.01 & 3.09 & 3.05 & 3.11 & 3.15 & 2.92 & 4.16 \\
\hline $\mathrm{CaO}$ & 8.74 & 6.88 & 8.58 & 8.74 & 8.77 & 8.65 & 8.17 & 8.31 & 8.43 & 8.68 & 8.71 & 9.70 \\
\hline $\mathrm{Na}_{2} \mathrm{O}$ & 3.33 & 3.14 & 3.37 & 3.45 & 3.36 & 3.39 & 3.34 & 3.37 & 3.35 & 3.34 & 3.44 & 3.05 \\
\hline $\mathrm{K}_{2} \mathrm{O}$ & 0.67 & 0.73 & 0.66 & 0.67 & 0.65 & 0.68 & 0.68 & 0.67 & 0.68 & 0.66 & 0.66 & 0.70 \\
\hline $\mathrm{P}_{2} \mathrm{O}_{5}$ & 0.12 & 0.13 & 0.12 & 0.12 & 0.12 & 0.12 & 0.12 & 0.12 & 0.12 & 0.12 & 0.11 & 0.30 \\
\hline L.O.I. & 0.86 & 1.55 & 0.87 & 0.83 & 0.85 & 0.86 & 1.07 & 0.94 & 0.86 & 0.85 & 0.83 & - \\
\hline $\mathrm{Rb}$ & 12.6 & 14.6 & 13.0 & 11.7 & 11.2 & 11.4 & 11.5 & 11.8 & 13.5 & 11.6 & 11.0 & \\
\hline $\mathrm{Sr}$ & 372 & 294 & 353 & 361 & 353 & 347 & 328 & 339 & 345 & 344 & 350 & \\
\hline $\mathrm{Ba}$ & 261 & 291 & 261 & 261 & 259 & 264 & 270 & 265 & 267 & 263 & 263 & \\
\hline Y & 20.0 & 23.8 & 21.9 & 21.5 & 21.4 & 21.7 & 21.8 & 21.3 & 21.7 & 21.9 & 21.3 & \\
\hline $\mathrm{Zr}$ & 123.0 & 106.0 & 88.7 & 87.9 & 82.6 & 92.4 & 87.8 & 84.7 & 87.5 & 84.8 & 82.9 & \\
\hline $\mathrm{Hf}$ & 3 & 3 & 2 & 2 & 2 & 2 & 2 & 2 & 2 & 2 & 2 & \\
\hline $\mathrm{Nb}$ & 5 & 2 & 1 & 1 & 1 & 1 & 1 & 1 & 1 & 1 & 1 & \\
\hline Th & 1.0 & 0.9 & 0.8 & 0.8 & 0.8 & 0.8 & 0.8 & 0.8 & 0.8 & 0.8 & 0.8 & \\
\hline $\mathrm{U}$ & 0.41 & 0.46 & 0.39 & 0.37 & 0.32 & 0.46 & 0.41 & 0.38 & 0.46 & 0.43 & 0.41 & \\
\hline La & 5.7 & 6.1 & 5.4 & 5.2 & 5.1 & 5.2 & 5.4 & 5.3 & 5.5 & 5.4 & 5.3 & \\
\hline $\mathrm{Ce}$ & 13.4 & 15.3 & 13.5 & 13.3 & 12.9 & 13.4 & 13.7 & 13.3 & 13.3 & 13.6 & 13.2 & \\
\hline Pr & 1.93 & 2.34 & 2.01 & 2.05 & 1.99 & 2.05 & 2.01 & 2.06 & 2.1 & 2.14 & 2.05 & \\
\hline $\mathrm{Nd}$ & 9.2 & 11.2 & 10.1 & 9.7 & 9.8 & 10.1 & 9.8 & 10.1 & 10.1 & 10.4 & 9.9 & \\
\hline $\mathrm{Sm}$ & 2.5 & 3.1 & 2.9 & 2.7 & 2.6 & 2.8 & 2.9 & 2.8 & 3.0 & 2.7 & 2.8 & \\
\hline $\mathrm{Eu}$ & 0.90 & 0.96 & 0.90 & 0.91 & 0.85 & 0.91 & 0.87 & 0.85 & 0.91 & 0.85 & 0.90 & \\
\hline Gd & 2.99 & 3.76 & 3.21 & 3.15 & 3.13 & 3.21 & 3.31 & 3.22 & 3.14 & 3.2 & 3.03 & \\
\hline $\mathrm{Tb}$ & 0.50 & 0.62 & 0.57 & 0.55 & 0.54 & 0.56 & 0.55 & 0.54 & 0.54 & 0.59 & 0.55 & \\
\hline Dy & 3.29 & 3.92 & 3.63 & 3.42 & 3.63 & 3.83 & 3.66 & 3.50 & 3.71 & 3.71 & 3.62 & \\
\hline Ho & 0.70 & 0.87 & 0.76 & 0.76 & 0.74 & 0.78 & 0.81 & 0.76 & 0.77 & 0.79 & 0.79 & \\
\hline $\mathrm{Er}$ & 2.09 & 2.51 & 2.26 & 2.25 & 2.16 & 2.24 & 2.39 & 2.33 & 2.28 & 2.32 & 2.1 & \\
\hline $\mathrm{Tm}$ & 0.30 & 0.36 & 0.35 & 0.32 & 0.34 & 0.33 & 0.33 & 0.33 & 0.35 & 0.34 & 0.36 & \\
\hline $\mathrm{Yb}$ & 1.9 & 2.4 & 2.3 & 2.1 & 2.1 & 2.1 & 2.2 & 2.0 & 2.2 & 2.1 & 2.1 & \\
\hline $\mathrm{Lu}$ & 0.36 & 0.37 & 0.36 & 0.35 & 0.32 & 0.34 & 0.36 & 0.34 & 0.35 & 0.37 & 0.34 & \\
\hline Co & 22.3 & 24.9 & 24.7 & 23.7 & 25.1 & 23.7 & 24.9 & 24.0 & 23.7 & 24.1 & 23.3 & \\
\hline V & 244 & 270 & 258 & 252 & 258 & 256 & 263 & 254 & 256 & 258 & 255 & \\
\hline $\mathrm{Cr}$ & 20 & 30 & 30 & 30 & 30 & 30 & 30 & 20 & 30 & 30 & 30 & \\
\hline Sc & 25 & 27 & 26 & 26 & 27 & 26 & 27 & 26 & 26 & 27 & 27 & \\
\hline $\mathrm{Ni}$ & 22 & 18 & 20 & 22 & 25 & 21 & 23 & 16 & 20 & 19 & 19 & \\
\hline $\mathrm{Ba} / \mathrm{La}$ & 45.8 & 47.7 & 48.3 & 50.2 & 50.8 & 50.8 & 50.0 & 50.0 & 48.5 & 48.7 & 49.6 & \\
\hline $\mathrm{Ce} / \mathrm{Y}$ & 0.67 & 0.64 & 0.62 & 0.62 & 0.60 & 0.62 & 0.63 & 0.62 & 0.61 & 0.62 & 0.62 & \\
\hline $\mathrm{Ba} / \mathrm{U}$ & 637 & 633 & 669 & 705 & 809 & 574 & 659 & 697 & 580 & 612 & 641 & \\
\hline $\mathrm{Rb} / \mathrm{Sr}$ & 0.03 & 0.05 & 0.04 & 0.03 & 0.03 & 0.03 & 0.04 & 0.03 & 0.04 & 0.03 & 0.03 & \\
\hline $\mathrm{Zr} / \mathrm{Y}$ & 6.15 & 4.45 & 4.05 & 4.09 & 3.86 & 4.26 & 4.03 & 3.98 & 4.03 & 3.87 & 3.89 & \\
\hline $\mathrm{La} / \mathrm{Yb}$ & 3.00 & 2.54 & 2.35 & 2.48 & 2.43 & 2.48 & 2.45 & 2.65 & 2.50 & 2.57 & 2.52 & \\
\hline $\mathrm{Ba} / \mathrm{Sr}$ & 0.70 & 0.99 & 0.74 & 0.72 & 0.73 & 0.76 & 0.82 & 0.78 & 0.77 & 0.76 & 0.75 & \\
\hline
\end{tabular}

Average basaltic andesite composition from the GEOROC database used for MELTS simulations.

green/yellowish in color and sizes from a few hundreds of microns up to $4 \mathrm{~mm}$. Compositions fall at the limit of diopside and augite fields on the QUAD diagram (Table 2; see also ESM1; Morimoto, 1988). Orthopyroxene is euhedral, grayish/pale brownish in color and sizes ranging between 1 and $3 \mathrm{~mm}$. Compositions fall in the field of enstatite on the QUAD diagram (Table 2; see also Table ESM1; Morimoto, 1988). Opaque oxides generally occur as euhedral to subhedral phenocrysts, small in size (up to $1 \mathrm{~mm}$ ). Major element analyses allow the classification of these opaque oxides as Ti-magnetite (Table 2; see also Table ESM1).

\subsection{Plagioclase textures and compositions}

Plagioclase ranges in composition between andesine and bytownite $\left(\mathrm{An}_{46-89}\right)$, with a $\mathrm{FeO}$ content generally variable between 0.5 and about 1 wt.\% (See ESM2). High-contrast BSE images coupled with core-to-rim compositional profiles have led to the definition of six main plagioclase textures, namely: Type 1, oscillatory-zoned crystals (Fig. 5a); Type 2, crystals with coarse sieve-textures (Fig. 5b); Type 3, patchy-zoned crystals (Fig. 5c, d); Type 4, crystals with strongly dissolved core (Fig. 5b, d); Type 5, crystals with strongly sieve-textured rim (Fig. 5e); Type 6, crystals with alignments of polygonal melt inclusions (Fig. 5f). The relative abundance of each identified texture is shown in Table 3.

Type 1 plagioclases exhibit compositional oscillatory zoning, a feature also reflected in their optical behavior (Figs. 5a and 6a). Clear, totally oscillatory-zoned plagioclase have generally size of $<1 \mathrm{~mm}$, whereas larger crystals commonly show the combination of more textures. As already evidenced for other volcanic systems (e.g., Ginibre et al., 2002b; Nicotra and Viccaro, in press; Viccaro et al., 2010), high-contrast BSE images coupled with core-to-rim chemical profiles evidenced two different patterns of oscillation: 1a) small amplitude and short wavelength and $1 \mathrm{~b}$ ) large amplitude and long wavelength. Type 1a displays short wavelength oscillation (generally $<10 \mu \mathrm{m}$ ) joined to limited variation of the An content $\left(\sim \Delta A n_{5}\right)$. Larger An variations $\left(\sim \Delta A n_{10}\right)$ were observed in the Type $1 \mathrm{~b}$ oscillation pattern with wavelength usually of 20-25 $\mu \mathrm{m}$. Type $1 \mathrm{~b}$ patterns also display frequent crenulated surfaces of dissolution or convoluted patterns with cross-cuttings, evidence of partial dissolution processes affecting the crystal. FeO content is rather constant throughout the core-to-rim profile in both the oscillation patterns. In some Type $1 \mathrm{~b}$ crystals, however, the outermost $100 \mu \mathrm{m}$ are characterized by coupled, gradual increase of the An and FeO contents. It is worth to note that Type 1 plagioclases are the dominant texture in all the analyzed lavas, and particularly in the AVA2 sample (Table 3). 

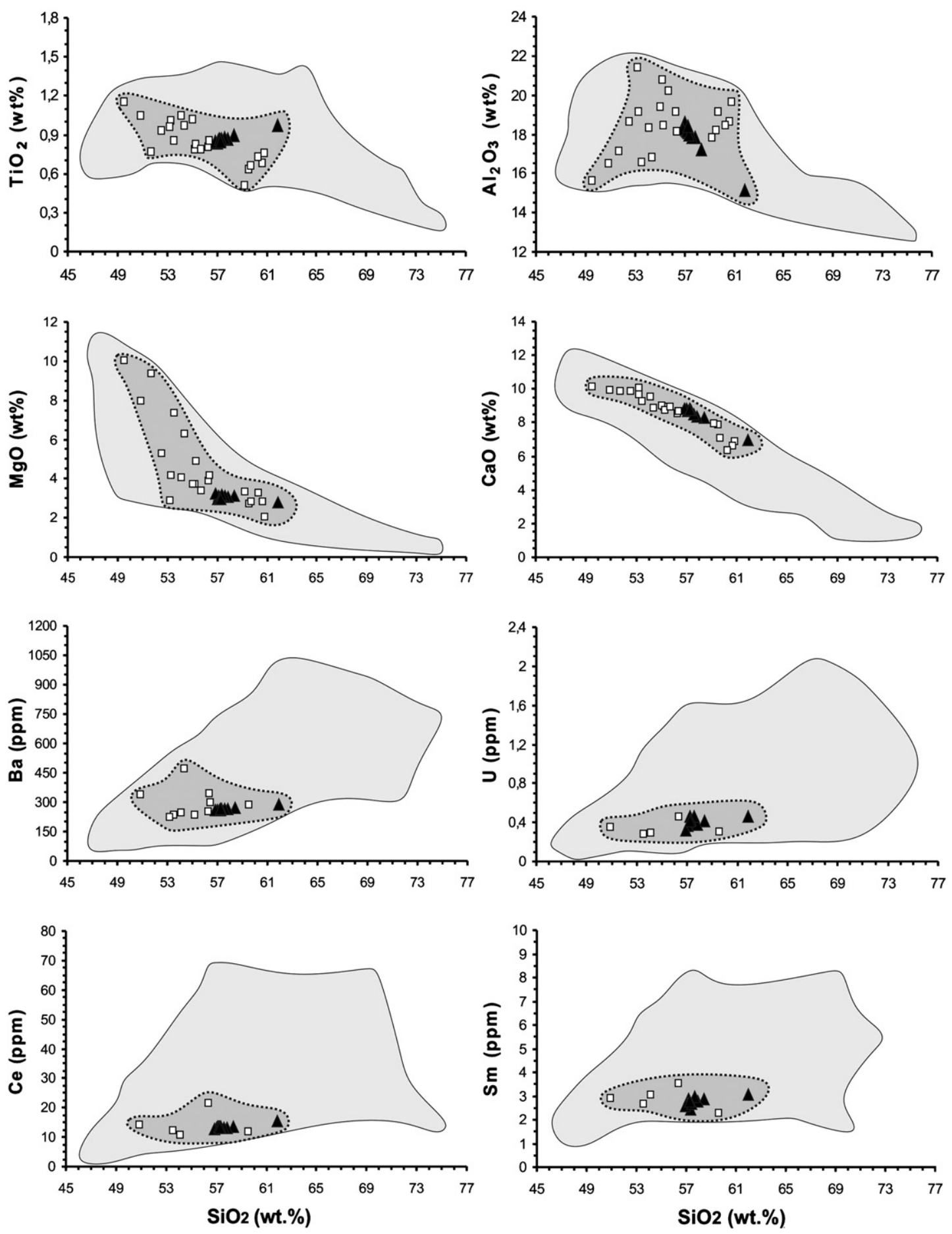

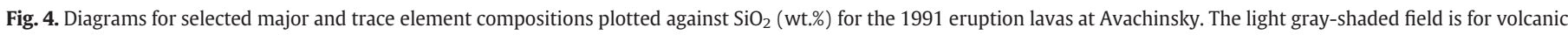
rocks of the Eastern Volcanic Front; the dark gray-shaded field is for other Avachinsky volcanic rocks. Symbols as in Fig. 3.

Type 2 plagioclases display coarse sieve-textures that are constituted by partially crystallized glass pockets variably distributed at the crystal core (Figs. 5b and $6 \mathrm{~b}$ ). This is the most frequent texture observed at the cores (except for AVA2; Table 3), especially in crystals larger than $1.5 \mathrm{~mm}$. Type 2 plagioclases commonly have An-rich cores $\left(\geq A n_{80}\right)$ characterized by Type $1 \mathrm{~b}$ oscillations throughout the profile. An contents abruptly decrease (up to $\Delta \mathrm{An}_{20}$ ) at the end of plagioclase cores with FeO content fairly constant (0.7-1 wt.\%). This texture, specific of the crystal cores, is generally followed by oscillatory zoning patterns or alignments of melt inclusions (see Type 6). In the smaller crystals $(<1 \mathrm{~mm})$, the Type 2 texture can be associated to strongly sieve-textured rims (see Type 5 ).

Type 3 plagioclases have patchy zoned core (Figs. 5c, d, and 6c). This rare texture (Table 3 ) is formed by irregularly-shaped patches up to $100-\mu \mathrm{m}^{2}$-wide with abrupt, large variations of the An content (from $\mathrm{An}_{55}$ to $\mathrm{An}_{80}$ ) between adjacent patches. $\mathrm{FeO}$ concentration in the Anpoor and An-rich patches is rather constant, ranging in general between 0.6 and 0.8 wt.\%. Only plagioclases larger than $1.5 \mathrm{~mm}$ display the Type 3 texture, which is somewhat rare in all the analyzed volcanic rocks (except in the AVA4 sample). Patchy cores can be superimposed by coarse 
Table 2

Average chemical compositions and relative standard deviations for clinopyroxene, orthopyroxene and opaque oxide of the 1991 eruption lavas at Avachinsky.

\begin{tabular}{|c|c|c|c|c|c|c|}
\hline & Clinopyroxene & \multirow[t]{2}{*}{$\sigma$} & \multirow{2}{*}{$\frac{\text { Orthopyroxene }}{n=20}$} & \multirow[t]{2}{*}{$\sigma$} & \multirow{2}{*}{$\frac{\text { Fe-Ti-oxide }}{n=20}$} & \multirow[t]{2}{*}{$\sigma$} \\
\hline & $n=20$ & & & & & \\
\hline $\mathrm{SiO}_{2}$ & 52.4 & \pm 0.7 & 53.9 & \pm 0.7 & / & / \\
\hline $\mathrm{TiO}_{2}$ & 0.60 & \pm 0.12 & 0.35 & \pm 0.09 & 10.3 & \pm 0.6 \\
\hline $\mathrm{Al}_{2} \mathrm{O}_{3}$ & 2.62 & \pm 0.77 & 1.23 & \pm 0.45 & 4.54 & \pm 0.38 \\
\hline $\mathrm{FeO}_{\text {tot }}$ & 8.97 & \pm 1.01 & 16.1 & \pm 1.4 & 80.7 & \pm 0.9 \\
\hline $\mathrm{MnO}$ & 0.38 & \pm 0.11 & 0.61 & \pm 0.13 & 0.60 & \pm 0.09 \\
\hline $\mathrm{MgO}$ & 15.9 & \pm 0.8 & 26.0 & \pm 1.1 & 3.79 & \pm 0.52 \\
\hline $\mathrm{CaO}$ & 18.7 & \pm 1.3 & 1.53 & \pm 0.16 & / & / \\
\hline $\mathrm{Na}_{2} \mathrm{O}$ & 0.47 & \pm 0.10 & 0.26 & \pm 0.06 & / & / \\
\hline
\end{tabular}

$n=$ number of analyses.

sieve-texture. As in the previous instance, envelopes that follow the core can show oscillatory zoning patterns (Type $1 \mathrm{~b}$ is the most frequent), alignments of melt inclusions or strongly resorbed rims.

Type 4 plagioclases are characterized by strongly developed dissolution surfaces that mark the edge of the crystal core (Figs. 5b, d, and $6 \mathrm{~b}, \mathrm{~d})$. The abundance of this texture is about $15 \%$ in basaltic andesites, whereas it is about $10 \%$ in the AVA2 andesite (Table 3). Within the core, plagioclase generally displays both types of oscillatory zoning. In correspondence of the dissolution surface sudden compositional changes towards markedly lower An with generally constant FeO content (0.7-1 wt.\%) are observed. Textures found at the outer portions of these crystals can be either strongly sieve-textured rims or alignments of melt inclusions (Types 5 and 6 , respectively).

Type 5 plagioclases are ubiquitous in the analyzed samples (Figs. 5e, 6d, e; Table 3). They show strongly resorbed rims marked by a sieve-textured envelope with average thickness of $\sim 70 \mu \mathrm{m}$. This sieved zone is made up of isolated and interconnected pockets of glass that is generally re-crystallized. In correspondence of the sieve-texture, the crystal records a significant increase of the An content (up to $\Delta \mathrm{An}_{20}$ ) at fairly constant $\mathrm{FeO}$ concentrations. The sievetextured envelope is usually followed by a thin $(\sim 10-20 \mu \mathrm{m})$ layer characterized by sudden decrease of the An content.

Also Type 6 plagioclases are ubiquitous in the volcanic rocks considered (Table 3). They are characterized by thin alignments of melt inclusions, polygonal in their shape, distributed along well-defined crystallographic planes that cut oscillatory zoning patterns (Figs. $5 \mathrm{f}$ and 6f). Alignments usually occur at the crystal rim, although some of them can mark the core of the crystals. A maximum of two alignments were observed along the core-to-rim profile. The envelope hosting melt inclusions exhibits a slight drop of the An content $\left(\sim \Delta \mathrm{An}_{5-10}\right)$ generally coupled with increase of the $\mathrm{FeO}$ concentrations ( $\Delta \mathrm{FeO} \sim 0.2 \mathrm{wt} . \%$ ).

\section{Crystal fractionation from whole rock geochemistry}

Magma differentiation processes such as crystal fractionation, recharge and mixing lead to compositional variations of the primary melt during ascent en-route to surface. The basaltic andesite to andesitic lavas of the 1991 eruption at Avachinsky Volcano reveal that crystal fractionation may be the main evolutionary process in the magmatic system to produce such evolved compositions. In order to constrain the role of crystal removal prior to the eruption, a crystal fractionation simulation was performed through the MELTS code (Ghiorso and Sack, 1995; Asimow and Ghiorso, 1998; Fig. 7). The starting melt composition was taken from an average of the less evolved basaltic andesites of the entire Avachinsky volcanic succession $\left(\mathrm{SiO}_{2}=\sim 53 \mathrm{wt} . \%\right.$; Table 1 dataset from GEOROC database, http://georoc.mpch-mainz.gwdg.de), assuming therefore that, after generation, the primary basaltic (s.l.) magma rose up at crustal levels and underwent slight differentiation. The chosen parameters reproduce an isobaric crystallization process into a magma chamber placed at $\sim 5.5 \mathrm{~km}$ of depth $(150 \mathrm{MPa})$ with temperature ranging between
$1150{ }^{\circ} \mathrm{C}$ and $1000{ }^{\circ} \mathrm{C}$. These values are in accordance with those estimated by Fedotov (1982), Fedotov et al., (2007) for a deep magma chamber at Avachinsky Volcano. The initial content of dissolved $\mathrm{H}_{2} \mathrm{O}$ was set at 2.0 wt.\%, whereas $\mathrm{fO}_{2}$ at the $\mathrm{QFM}+1$ buffer. Dissolved water contents obtained at the end of the modeling ( $2.7 \mathrm{wt} . \%)$ for melt compositions matching the 1991 eruption lavas are in accordance with those measured in olivine-hosted melt inclusions (basaltic andesites in composition) from other Kamchatka volcanic systems where the subducting slab has depth similar to that estimated beneath Avachinsky Volcano (Portnyagin et al., 2007). Values for oxygen fugacity are within the range of those assumed by Portnyagin et al. (2005) for other magmas at Avachinsky Volcano $(\mathrm{QFM}+0.5-\mathrm{QFM}+2)$. The resulting crystallization trends for major oxides are plotted together with the 1991 lavas and all the other available data for the Avachinsky volcanic rocks (database from GEOROC; Fig. 7). The simulation under these conditions shows that the 1991 basaltic andesites can be explained by fractionation of plagioclase $\sim \mathrm{An}_{70-82}$ (3-27 wt.\%), augitic clinopyroxene (10-12 wt.\%), orthopyroxene (1-4 wt.\%) and opaque oxide (2-6 wt.\%). The AVA2 andesite was not considered in the simulation given that several major oxide compositions may reflect some extent of alteration. Fractional crystallization was also simulated through a Rayleigh model for trace elements (Fig. 7). An average of the less evolved basaltic andesites, for which trace elements are available from literature (database from GEOROC), was used as starting composition for the simulation. Distribution coefficients used are from GERM database at http://earthref.org/GERM/ (query for "basalt-andesite" melts and relative solid phases). Results show that trace element variations of the 1991 eruption lavas are consistent with fractionation from the poorly evolved basaltic andesite of an assemblage constituted by plagioclase, clinopyroxene, orthopyroxene and opaque oxide with the same proportions as for major oxides.

The use of whole rock geochemistry is, however, not enough to provide a comprehensive picture of the feeding system dynamics at Avachinsky Volcano. In the next chapter, more complex differentiation dynamics have been unraveled through the integration of textural and compositional features recorded by plagioclase crystals.

\section{Plagioclase to decipher other magmatic processes at Avachinsky}

High-contrast BSE images coupled with compositional profiles of plagioclase crystals gave the opportunity to unravel the mechanisms of magma ascent and storage in feeding system of Avachinsky Volcano. Six types of plagioclase textures were found in the 1991 eruption lavas, which reflect either episodes of destabilization or changes in growth rate during crystallization.

Type 1 plagioclase showed two zoning patterns with different amplitude and wavelength of the oscillation (Figs. 5a and 6a). The development of these two different patterns has been explained as related to different crystallization mechanisms (Ginibre et al., 2002a; 2002b; Humphreys et al., 2006; Pearce and Kolisnik, 1990; Viccaro et al., 2010). Oscillations characterized by small amplitude coupled with short wavelength seem to be caused by small-scale crystallization kinetics at the crystal/melt interface in magmatic reservoirs not affected by significant convective movements (Allegre et al., 1981; Anderson, 1984; Holten et al., 2000; L'Heureux, 1993; Ortoleva, 1990). Type 1a oscillatory zoning, which was found especially at the core of the crystals, may therefore suggest that crystallization in the deeper portions of the Avachinsky plumbing system is rather calm. On the other hand, large amplitude and long wavelength oscillations should testify changes, although small, in the physical and chemical conditions of the magmatic system. Such interpretation finds its rationale on the occurrence of convolution and crenulated surfaces in some of the plagioclase envelopes with Type 1b oscillations, which can be related to incipient, minor episodes of dissolution (Nicotra and Viccaro, in press; Pearce and Kolisnik, 1990; Singer et al., 1995; Viccaro et al., 2010). Convection into magma reservoirs can move 


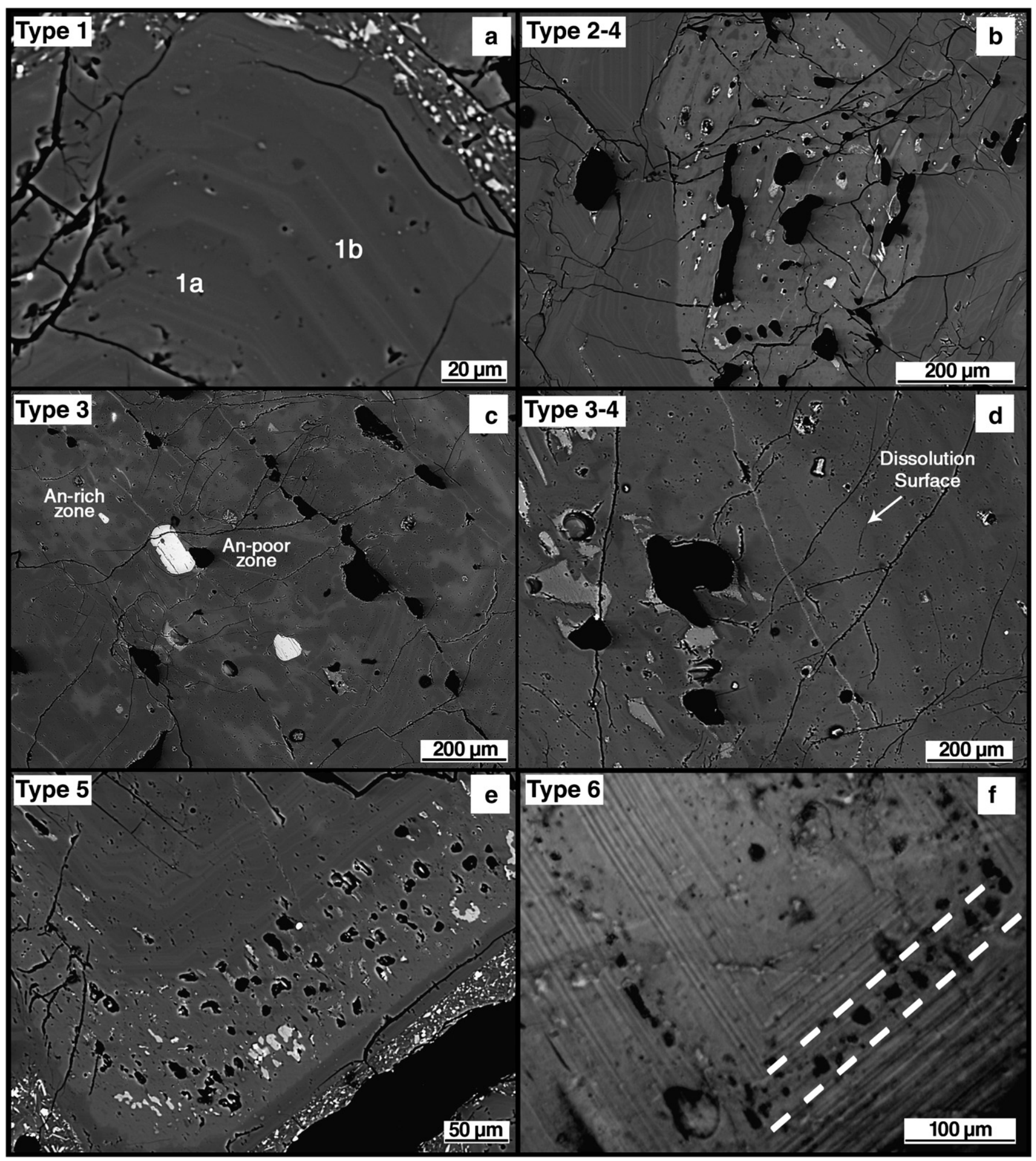

Fig. 5. a-e) High-contrast back-scattered photos by scanning electron microscope for different plagioclase texture types. a) Oscillatory zoning patterns in plagioclase crystals: 1a indicates patterns characterized by small amplitude and short wavelength oscillations, whereas $1 \mathrm{~b}$ those with large amplitude and long wavelength; $b$ ) plagioclase crystal with a marked dissolution surface that bounded the core, which is also affected by coarse sieve-textures; c) plagioclase with patchy-zoned core constituted by adjacent An-rich and An-poor zones; d) particular of a plagioclase core affected by both patchy zoning and dissolution; e) plagioclase crystal with highly-developed sieve-texture at the rim. f) Image at the optical microscope (plane pol. light) of a plagioclase crystal with thin alignments of polygonal melt inclusions.

crystals along physical and chemical gradients. The result is that crystals cyclically move within a melt characterized by small changes in temperature and/or volatile contents, which finally cause minor changes in the plagioclase composition with possible development of minor dissolution surfaces if $\Delta \mathrm{T}$ and $\Delta$ volatiles are more significant. Some of the crystals with Type $1 \mathrm{~b}$ zoning display gradual, joined increases of the An and, to a minor extent, FeO contents. This behavior could be explained with gradual compositional changes registered by 
Table 3

Modal abundance of the texture types in plagioclase phenocrysts of the 1991 lavas. at Avachinsky, resulting from the analysis under optical microscope.

\begin{tabular}{|c|c|c|c|c|c|c|}
\hline & AVA1 & AVA2 & AVA4 & AVA5 & AVA7 & AVA8 \\
\hline & $39 \%$ & $46 \%$ & $40 \%$ & $41 \%$ & $40 \%$ & $38 \%$ \\
\hline Type 2 & $21 \%$ & $14 \%$ & $20 \%$ & $19 \%$ & $20 \%$ & $21 \%$ \\
\hline Type 3 & $2 \%$ & $1 \%$ & $3 \%$ & $2 \%$ & $1 \%$ & $2 \%$ \\
\hline Type 4 & $16 \%$ & $10 \%$ & $17 \%$ & $15 \%$ & $14 \%$ & $17 \%$ \\
\hline Type 5 & $13 \%$ & $18 \%$ & $11 \%$ & $15 \%$ & $20 \%$ & $12 \%$ \\
\hline Type 6 & $9 \%$ & $11 \%$ & $9 \%$ & $8 \%$ & $5 \%$ & $10 \%$ \\
\hline
\end{tabular}

the hosting melt that do not lead to evident texture development (a sort of cryptic mixing; cf. Humphreys et al., 2006).

Oscillatory zoning in plagioclases indicates that the crystallization occurs fairly close to equilibrium conditions. In contrast, abrupt textural and compositional changes ( $\triangle \mathrm{An}_{20}$ or higher) have been usually ascribed to major physical and chemical perturbations of the system, which change the phase equilibria producing modifications of the plagioclase stability field. Disequilibrium textures such as Types 2, 3 and 4 , which were found in the largest plagioclases, testify episodes of crystal dissolution/resorption (Figs. $5 \mathrm{~b}-\mathrm{d}$ and $6 \mathrm{~b}-\mathrm{d}$ ). The processes responsible for such textures still are matter of great debate (Streck, 2008 and references therein). Some authors attributed dissolution/resorption textures to heating as a consequence of input by hotter magma into the residing system (cf. Tsuchiyama and Takahashi, 1983). In our case, this explanation seems to be not reasonable, as the compositional profiles at the plagioclase cores do not show evidence of significant changes of the evolutionary degree of the melt (and therefore of temperature). Furthermore, the coexistence of Types 1, 2 and 3 textures, which were found in crystals of comparable size, cannot be related to a unique destabilizing process. Conversely, experimental results demonstrated that magma decompression at water-undersaturated conditions can cause a progressive increase in the partial volatile pressure of the system, which in turn reduce the plagioclase stability field and shift its equilibrium to more calcic compositions (Blundy and Cashman, 2001; Nelson and Montana, 1992). Based on this general statement, different types of dissolution textures may be acquired at variable rates of decompression of the magmatic system. The fairly constant FeO at variable An content confirms the predominant role of a physical parameter more than chemical perturbation of the system. In this regard, patchy zoning (Type 3) may be accounted for by dissolution of a sodic plagioclase (that remains as an irregular relic) followed by regrowth of a more calcic plagioclase (cf. Ginibre and Wörner, 2007; Humphreys et al., 2006). Reasonably, this process should be favored by slow ascent rates, since adequate time is needed for crystal dissolution and regrowth. Plagioclases with dissolved cores (Type 4) record exclusively episodes of dissolution/resorption that involve a considerable part of the crystal. Plagioclase crystals can be effectively destabilized by a dramatic increase of the decompression rate. If the ascent rate moderately increases, such texture may be also formed with higher water contents dissolved in the melt (cf. Nelson and Montana, 1992). In this scenario, coarse sieve-textures (Type 2), which produce only partial crystal dissolution, might be viewed as an incipient Type 4, acquired therefore at decompression rates intermediate than those required for Type 3 and Type 4 textures, or comparable rates with Type 4 coupled with lower dissolved water in the melt. In any case, the coexistence of contrasting textures types at the core of plagioclase crystals is evidence for physically unconnected pathways of magma ascent from the deeper to shallower levels of the plumbing system. As a result, these cores may represent older crystal "debris" from earlier magmatic pulses, later reactivated and re-entrained into the ascending 1991 eruption magma batch.

Strongly sieve-textured rims (Type 5 ) are characterized by sudden increase of An at quite unvarying FeO contents (Fig. 6d-e). Several experimental results provide clear evidence that similar textures are the effect of the injection with consequent mixing by less evolved, possibly hotter and volatile-rich magma into more evolved, residing systems (Nakamura and Shimakita, 1998; Tsuchiyama, 1985). Recharge by less evolved and/or hotter magma triggers the partial resorption of plagioclase shifting the equilibrium to more calcic terms. Evidence of this texture suggests therefore the occurrence of a mixing process prior to the 1991 eruption between two distinct end-members. The behavior of An and FeO seem to suggest that the recharging magma should be characterized by rather comparable evolutionary degree although with higher temperature and volatile contents than the residing one. Petrographic observations revealed that Type 5 texture is not ubiquitously present in crystals with similar sizes, probably indicating that mixing was not sufficiently efficient to involve the entire residing magma body and/or that it occurred shortly before the eruption. In this regard, it is also noteworthy that the AVA2 andesite shows dominant oscillatory-zoned plagioclases and very scarce abundance of textures attributed to mixing, supporting the previous inference. The width of the sieve-textured envelopes depends on the duration of the disequilibrium conditions induced by the mixing (Clynne, 1999). Widths of the envelopes in the 1991 eruption lavas at Avachinsky are generally in the order of $100 \mu \mathrm{m}$. Plagioclase growth rates in volcanic systems range within a wide range of values, depending on the melt composition and the undercooling degree. Growth rates range between $10^{-9}$ and $10^{-10} \mathrm{~mm} / \mathrm{s}$ for basaltic systems, whereas for andesitic systems at rather low pressure, they are in the order of $10^{-10} \mathrm{~mm} / \mathrm{s}$ (Cashman, 1990; Higgins, 1996). The plagioclase growth rate can however increase by some orders of 

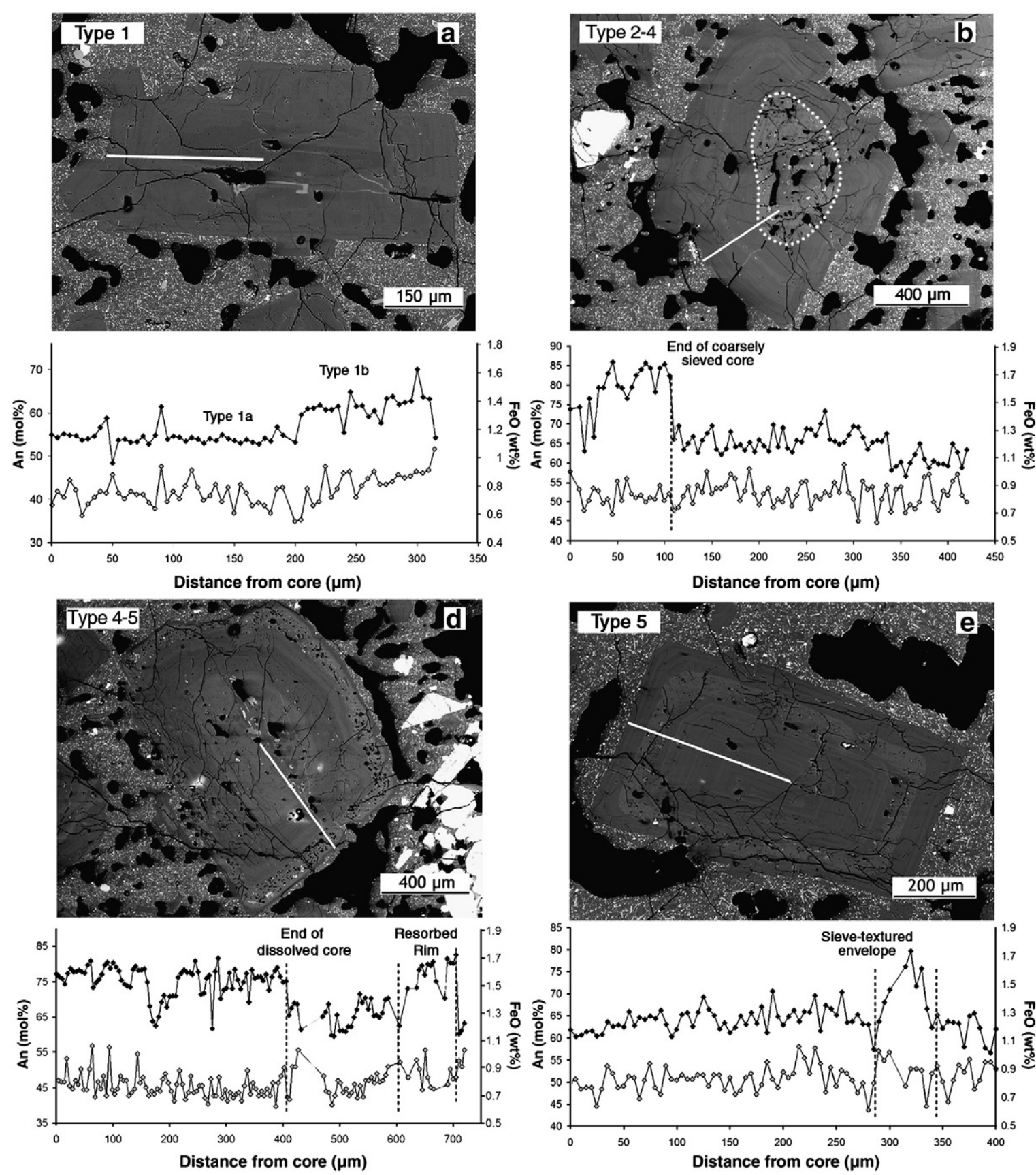
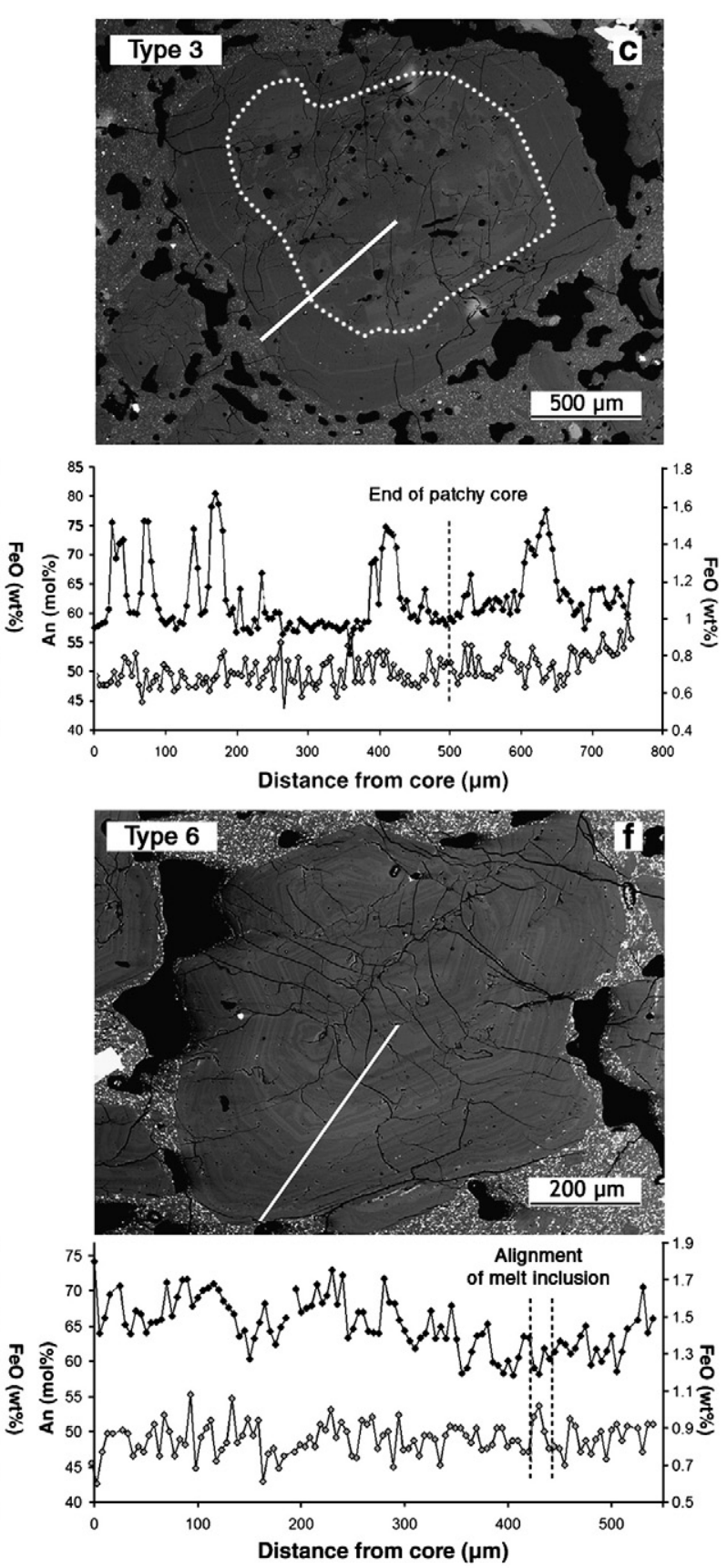

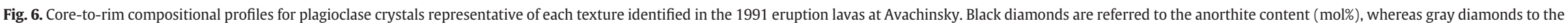
FeO content (wt.\%). 

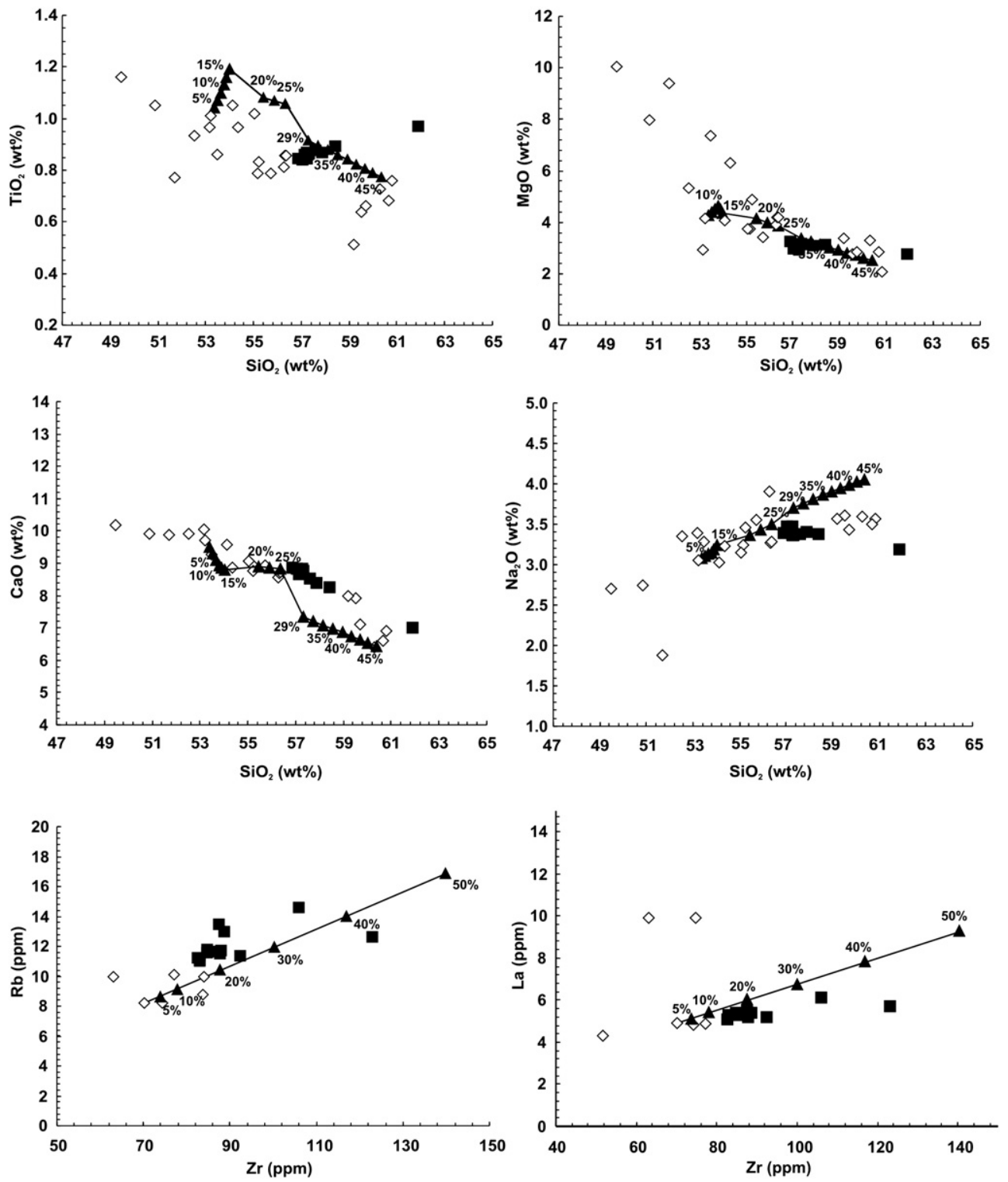

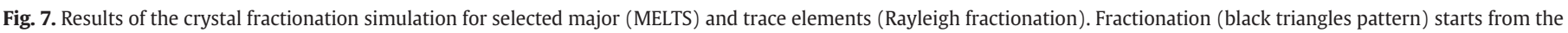

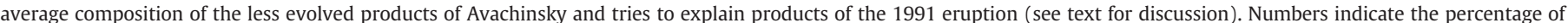

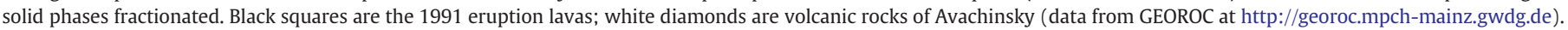

magnitude $\left(10^{-7}-10^{-8} \mathrm{~mm} / \mathrm{s}\right.$; Cashman, 1990) at elevated undercooling conditions, caused for example by mixing between evolved, cooler magmas and basic, hotter ones. Also massive volatile exsolution can lead to undercooling with consequent increase of the plagioclase growth rates (Cashman, 1990; Hammer and Rutherford, 2002). Considering $10^{-8} \mathrm{~mm} / \mathrm{s}$ and $10^{-7} \mathrm{~mm} / \mathrm{s}$ as a possible range for the crystal growth rates (assuming therefore different degrees of undercooling), the $100 \mu \mathrm{m}$-thick envelope in plagioclase of the 1991 eruption lavas at Avachinsky may be formed in a time interval ranging between $\sim 4$ months and $\sim 2$ weeks. The development of these textures and the timescales derived suggest that a recharging phase occurred less than 4 months before the eruption could have destabilized the volcano feeding system and effectively triggered the eruption.

Plagioclase crystals characterized by alignments of melt inclusions distributed along well-defined crystallographic directions (Type 6) can be the result of fast growth at elevated undercooling under oxidizing conditions. Envelopes with these inclusions record a sudden drop of An coupled with increase of the FeO content (Fig. 6f). Experimental results established that pressure release coupled with volatile exsolution from the melt strongly increases the stability field of plagioclase, shifting the equilibrium towards more sodic compositions (cf. Blundy and Cashman, 2001, 2005). Under these conditions, the crystal is characterized by a fast growth of a sodic envelope that can entrap small portions of the surrounding melt. The occurrence of several concentric alignments of melt inclusions in plagioclases of the Avachinsky lavas can be related to numerous steps of decompression with volatile loss from the system, which may imply the existence of distinct magma storage levels at various crustal depths.

\section{Some physical and chemical constraints}

The MELTS simulations at a constant range of temperature, $\mathrm{H}_{2} \mathrm{O}$ content and oxygen fugacity revealed that the 1991 eruption lavas at Avachinsky could be produced by crystal fractionation at $150 \mathrm{MPa}$, corresponding to $\sim 5.5 \mathrm{~km}$ of depth below the summit of the volcano with a rock density of $2600 \mathrm{~kg} / \mathrm{m}^{3}$. Such a value is in agreement with that proposed by Fedotov (1982), Fedotov et al. 
(2007), who inferred the existence of a main reservoir at this depth beneath the Avachinsky Volcano.

Concerning the crystallization temperature of plagioclase, some semi-quantitative indications can be obtained through the geothermometer of Putirka (2005), which is based on the plagioclase-melt equilibrium at given pressure values and the $\mathrm{H}_{2} \mathrm{O}$ contents of the magmatic system. It is worthwhile that the geothermometer is not markedly pressure sensitive, which means that even uncertainties of some MPa that result from the previous pressure estimation do not produce important temperature changes. The chosen values for pressure and dissolved $\mathrm{H}_{2} \mathrm{O}$ in the melt for the magmatic systems are in accordance with those of the MELTS simulation (respectively, $150 \mathrm{MPa}$ and $2.7 \mathrm{wt} . \%$ ). Calculations were done only for some of the plagioclase textures, as too many assumptions are necessary in some instances to constrain the variables of the system (e.g., patchy zoning). The melt composition in equilibrium with the crystal was taken from plagioclase-hosted melt inclusions of some andesites erupted at Avachinsky Volcano (Tolstykh et al., 2002). Specifically, the melt inclusion used for calculations is dacitic in composition (sample 96002, $\mathrm{SiO}_{2}=66.34$ wt.\% and inferred $\mathrm{H}_{2} \mathrm{O} \sim 2.5$ wt.\%; data from Tolstykh et al., 2002). This inclusion could be assumed as representative of the melt from which plagioclase is crystallizing, in a magmatic system with basaltic andesite-andesitic composition. On the whole, the resulting plagioclase crystallization temperatures along the core-to-rim profiles range between $\sim 1050{ }^{\circ} \mathrm{C}$ and $\sim 1060{ }^{\circ} \mathrm{C}$. The values obtained are in accordance with the measured homogenization temperature $\left(1060{ }^{\circ} \mathrm{C}\right)$ for plagioclase-hosted inclusions of similar composition. These values are considered representative of the temperature in the magma reservoir at $150 \mathrm{MPa}$. Calculations were also performed using a more evolved plagioclase-hosted melt inclusion as composition in equilibrium with the outer portion of the plagioclase crystals [sample 96002(b), $\mathrm{SiO}_{2}=72.21$ wt.\% and $\mathrm{H}_{2} \mathrm{O}=4.75$ wt.\%; data from Tolstykh et al., 2002]. Crystallization temperatures at these conditions mark a substantial decrease, being in the range of $960-980^{\circ} \mathrm{C}$. These temperatures may be representative of the syn-eruptive stage.

With some assumptions, the Putirka (2005) geothermometer gives useful indications for some specific plagioclase textures found in the 1991 eruption lavas at Avachinsky. Concerning the Type 1a oscillations, the minor changes in anorthite occur at fairly constant temperature (changes are in the order of only $\sim{ }^{\circ} \mathrm{C}$ ), which suggests the primary role of crystallization kinetics. In the case of Type $1 \mathrm{~b}$ oscillations with anorthite variation up to $\Delta \mathrm{An}_{9}$, temperature can be kept fairly constant $\left(\Delta \mathrm{T}<3{ }^{\circ} \mathrm{C}\right)$ by small changes of the $\mathrm{H}_{2} \mathrm{O}$ content ( $<0.05$ wt.\%). Type $1 \mathrm{~b}$ oscillatory zoning agrees well with convection into the magma reservoir that moves the plagioclase crystals along very scarce gradients of temperature and volatile contents. Type 4 crystals, characterized by dissolved cores, record a sudden An drop $\left(\triangle A n_{15-18}\right)$ at constant $\mathrm{FeO}$ at the core boundary. This behavior, which cannot be accounted for by compositional changes of the magmatic system, has been attributed to volatile loss from the system after decompression at elevated ascent rates. If no major temperature variation occurs (although volatile exsolution causes some extent of undercooling), the An decrease is explained by $~ 0.15 \mathrm{wt} . \%$ of water loss from the system. The water amount is lowered if volatile loss is coupled with temperature decrease (e.g., $~ 0.1 \mathrm{wt} . \%$ for temperature decrease of $\sim 5^{\circ} \mathrm{C}$ ). Plagioclase crystals of the 1991 eruption lavas at Avachinsky show almost ubiquitously marked sieve-textured rims, which record An increase at constant FeO contents. We have attributed the development of this texture to mixing between a residing magma and a hotter end-member at rather comparable evolutionary degree. Maintaining for the melt the same evolutionary degree, the anorthite variation (up to $\Delta \mathrm{An}_{20}$ ) observed in correspondence of the sieve-textured rims matches with a temperature increase of 15-

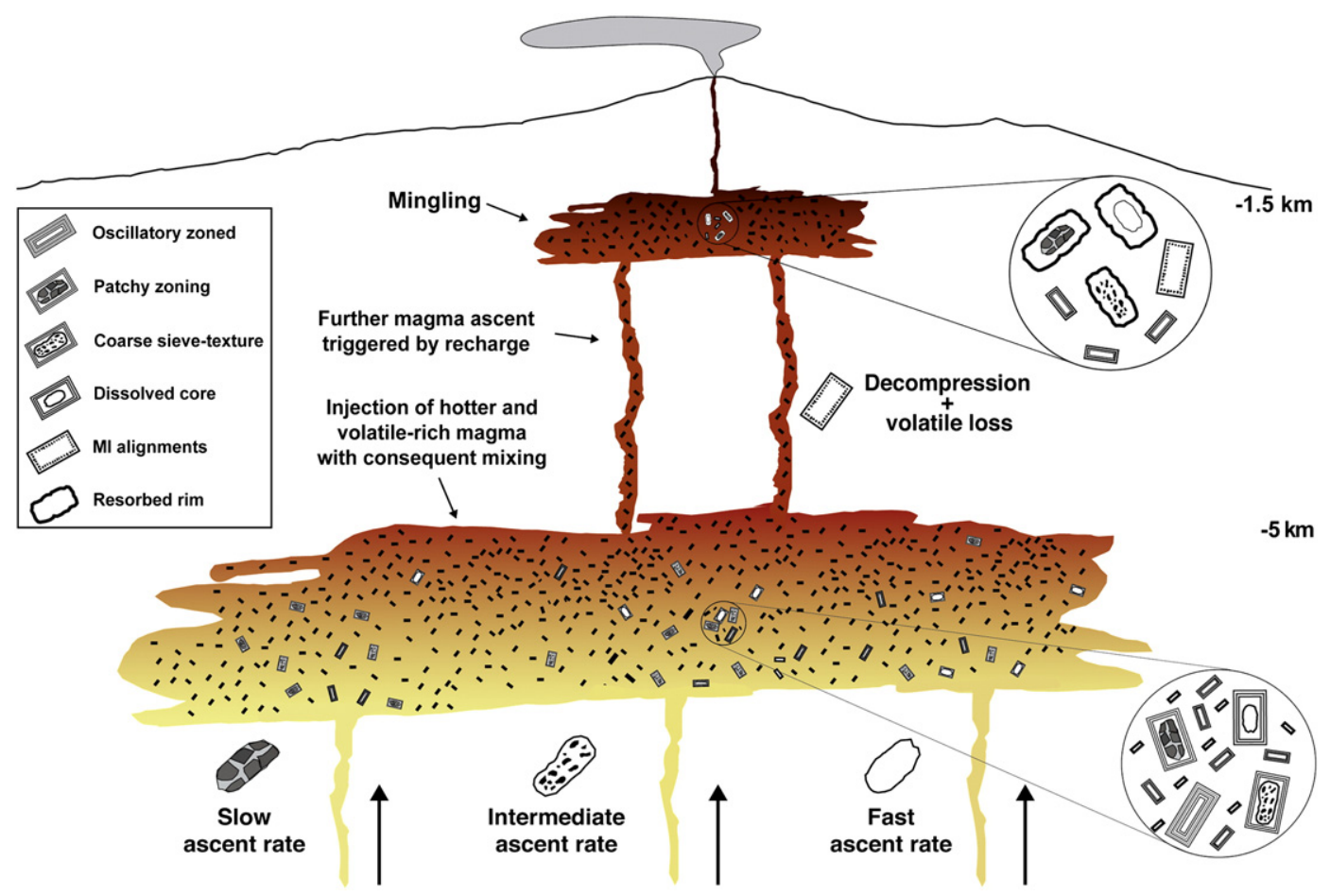

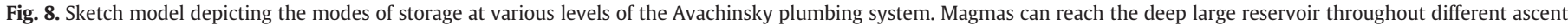

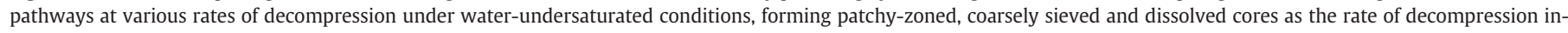

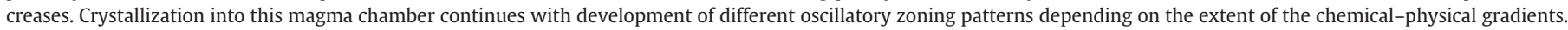

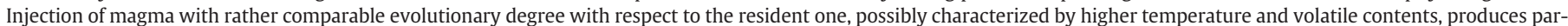

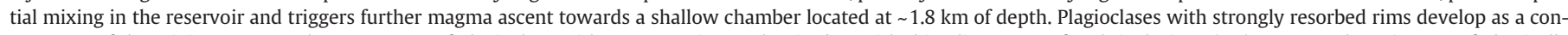

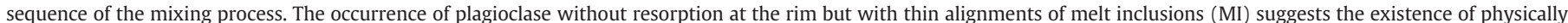

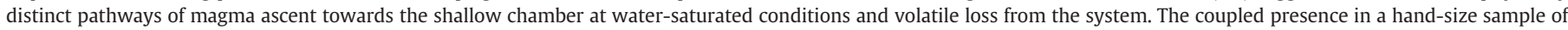

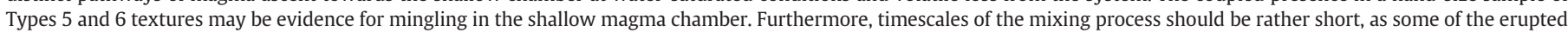
products do not show evidence of disequilibrium textures (e.g., the AVA2 sample exhibits prevalent oscillatory-zoned plagioclase). 
$20{ }^{\circ} \mathrm{C}$. If the temperature increase is also coupled with an increase of the total volatile content (i.e., the intruding magma is hotter and more volatile-rich) the anorthite variations can be adjusted by temperature increase of $10-15^{\circ} \mathrm{C}$ and addition of $\sim 0.15 \mathrm{wt} . \%$ of dissolved water. The thin plagioclase layers enclosing melt inclusions, characterized by sharp An decrease and $\mathrm{FeO}$ increase, were attributed to volatile loss from the system under oxidizing conditions as a response of decompression. Some extent of undercooling is reasonable even in this case; however, if we assume temperature rather constant during the ascent, 0.1 wt.\% of exsolved water $\mathrm{H}_{2} \mathrm{O}$ adjusts the observed anorthite variations.

Semi-quantitative indications on the volatile saturation pressure for the Avachinsky magmatic system are hard to be obtained. Solubility models for system compositionally comparable to that of Avachinsky are scarce in literature (e.g., Pineau et al., 1998). The model of Pineau et al. (1998) is based on several experiments of solubility for the system basaltic andesite- $\mathrm{H}_{2} \mathrm{O}$ (samples of Klyuchevskoyi Volcano, Kamchatka) at $1250{ }^{\circ} \mathrm{C}$ and pressure ranging between 50 and $300 \mathrm{MPa}$. For water contents of $2.7 \mathrm{wt}$.\% the exsolution depth is $<100 \mathrm{MPa}$. Other models are based on the equilibrium between gas and volatiles in the liquid for silicate melt $-\mathrm{H}_{2} \mathrm{O}-\mathrm{CO}_{2}$ systems (e.g., Papale, 1999; Papale et al., 2006). These models highlight how much is different the solubility of a multi-component vs. one component gas phase and, moreover, the non-ideal, non-linear roles of the liquid composition in the multicomponent gas-liquid equilibria. This results in complex volatile saturation curves. The lack of any information, even inferred, about the dissolved $\mathrm{CO}_{2}$ for the Avachinsky magmas at depth strongly limits the application of these models.

\section{Inferences on the plumbing system geometry}

The above discussions and interpretations of the textures development under peculiar chemical and physical conditions allow some inferences on the geometry of the plumbing system at Avachinsky Volcano. The occurrence at the plagioclase cores of three distinct types of textures (patchy zoning, coarse sieve-textures, dissolved cores) is an indication that styles of magma ascent at water-undersaturated conditions are different. This may be caused by variable rates of decompression that characterize the deep levels of the plumbing system, which is evidence of physically distinct magma ascending pathways towards the surface (crystals with distinct cores have almost similar sizes). At shallower, water saturated conditions, plagioclase textures and compositional profiles suggest that crystallization generally continues in reservoir/s not significantly affected by chemical and physical perturbations (oscillatory zoning develops). This may be evidence of either scarce magma replenishment from depth or that a large volume of magma is able to buffer minor, new magma pulses. However, the occurrence of distinct patterns of oscillation, even within the same crystal, put forward the idea that crystals can encounter different dynamic regimes throughout their growth history. A similar behavior suggests that some convection should take place at shallow levels, implying the presence of at least one magma body of considerable size (Fedotov, 1982; Fedotov et al., 2007). The occurrence of only two types of textures that cut the oscillatory zoning patterns at the plagioclase rims (almost ubiquitous strongly developed sieve-textures or, to a minor extent, thin alignments of melt inclusions) is evidence that crystals undergo rather common histories at shallow levels of the plumbing system, favoring the hypothesis of the existence of a large magma reservoir whose top is at $\sim 5.5 \mathrm{~km}$ of depth (in accordance with Fedotov et al., 2007), more than several separated batches (Fig. 8). Furthermore, the presence in a hand-size sample of these two types of textures, which are sometimes not coupled, implies that crystals have the chance to mix mechanically at very shallow levels after uprise through distinct ascending pathways. This may confirm the existence of a small, superficial magma reservoir at $\sim 1.8 \mathrm{~km}$ of depth (Fig. 8; cf. Melekestsev et al., 1994b), where crystals that record different growth histories finally meet.
If the above assumptions are correct, the textural and compositional features revealed by plagioclase crystals could suggest the following pre-eruptive model (Fig. 8):

1) A more hot and volatile-rich magma may have intruded in the reservoir at $\sim 5 \mathrm{~km}$ of depth, where the compositional difference with respect to the large volume of the residing magma was partially buffered.

2) This replenishment induced further magma ascent and intrusion into the small magma reservoir at $1.8 \mathrm{~km}$.

3) The occurrence of the AVA2 andesite, characterized by prevalent oscillatory-zoned plagioclase without evident disequilibrium textures, suggests that mixing had not produced complete homogenization into the small magma chamber.

4) The mixing process in the shallow magma chamber may be viewed as the eruption triggering mechanism, since it should be occurred less than 4 months before the January 1991 event. In accordance to what suggested by Melekestsev et al. (1994b), given the very scarce volume of magma involved, the eruption may have been fed exclusively by magma stored in the reservoir at $1.8 \mathrm{~km}$ of depth.

Supplementary materials related to this article can be found online at doi:10.1016/j.lithos.2012.01.019.

\section{Acknowledgments}

MV is indebted to friends Feodor Farberov and Levente Varhelyii, who made possible the volcanological expedition in Kamchatka between July and August 2004. The Authors would also like to express gratitude to Renato Cristofolini for his ever-present, crucial suggestions during the work preparation. An early version of the manuscript benefited of the critical revisions by Pavel Plechov and Gerhard Wörner, who are kindly thanked. Nelson Eby is very much thanked for his editorial guidance, Wendy Bohrson and an anonymous reviewer really improved the final version of the manuscript with their attentive comments and suggestions. This study was made possible through research grants to MV from the University of Catania (Italy).

\section{References}

Allegre, C.J., Provost, A., Jaupart, C., 1981. Oscillatory zoning: a pathological case of crystal growth. Nature 294, 223-228.

Anderson Jr., A.T., 1984. Probable relation between plagioclase zoning and magma dynamics, Fuego Volcano, Guatemala. American Mineralogist 68, 125-129.

Asimow, P.D., Ghiorso, M.S., 1998. Algorithmic modifications extending MELTS to calculate subsolidus phase relations. American Mineralogist 83, 1127-1131.

Auer, S., Bindeman, I. Wallace, P. Ponomareva, V., Portnyagin, M., 2009. The origin of hydrous, high- $\delta^{18} \mathrm{O}$ voluminous volcanism: diverse oxygen isotope values and high magmatic water contents within the volcanic record of Klyuchevskoy Volcano, Kamchatka, Russia. Contributions to Mineralogy and Petrology 157, 209-230.

Avdeiko, G.P., Palueva, A.A., Khleborodova, O.A., 2006. Geodynamic conditions of volcanism and magma formation in the Kurile-Kamchatka island-arc system. Petrology $14,230-246$

Braitseva, O.A., Bazanova, L.., Melekestsev, I.V., Sulerzhitskiy, L.D., 1998. Large Holocene eruptions of Avacha Volcano, Kamchatka ( $7250-3700{ }^{14} \mathrm{C}$ years B.P.). Journal of Volcanology and Seismology 20, 1-27.

Braitseva, O.A., Melekestsev, I.V., Ponomareva, V.V., Sulerzhitskiy, L.D., 1995. The ages of calderas, large explosive craters and active volcanoes in the Kuril-Kamchatka region, Russia. Bulletin of Volcanology 57, 383-402.

Braitseva, O.A., Ponomareva, V.V., Sulerzhitsky, L.D., Melekestsev, I.V., 1997. Holocene key-marker tephra layers in Kamchatka, Russia. Quaternary Research 47, 125-139.

Blundy, J.D., Cashman, K.V., 2001. Ascent-driven crystallization of dacite magmas at Mount St. Helens, 1980-1986. Contributions to Mineralogy and Petrology 140, 631-650.

Blundy, J.D., Cashman, K.V., 2005. Rapid decompression-driven crystallization recorded by melt inclusions from Mount St, Helens Volcano. Geology 33, 793-796.

Cashman, K.V., 1990. Textural constraints on the kinetics of crystallization of igneous rocks. In: Nicholls, J., Russell, J.K. (Eds.), Modern Methods of Igneous Petrology, Understanding Magmatic Process. : Reviews in Mineralogy, 24. Mineralogical Society of America, Washington D.C., pp. 259-314.

Clynne, M.A., 1999. A complex magma mixing origin for rocks erupted in 1915, Lassen Peak, California. Journal of Petrology 40, 105-132.

Costa, F., Chakraborty, S., Dohmen, R., 2003. Diffusion coupling between trace and major elements and a model for calculation of magma residence times using plagioclase. Geochimica et Cosmochimica Acta 67, 2189-2200. 
Davidson, J.P., Tepley, F.J., 1997. Recharge in volcanic systems: evidence from isotope profiles of phenocrysts. Science 275, 826-829.

Erlikh, E.N., 1966. The Petrochemistry of the Kuril-Kamchatka Volcanic Province (In Russian). Nauka, Moscow.

Fedotov, S.A., 1982. Temperatures of entering magma, formation and dimensions of magma chambers of volcanoes. Bulletin of Volcanology 45, 334-347.

Fedotov, S.A., Sugrobov, V.M., Utkin, I.S., Utkina, L.I., 2007. On the possibility of using heat stored in the magma chamber of the Avachinsky Volcano and the surrounding rock for heat and power supply. Journal of Volcanology and Seismology 1, 28-41.

Ginibre, C., Wörner, G., 2007. Variable parent magmas and recharge regimes of the Parinacota magma system ( $\mathrm{N}$. Chile) revealed by $\mathrm{Fe}, \mathrm{Mg}$, and $\mathrm{Sr}$ zoning in plagioclase. Lithos 98, 118-140.

Ginibre, C., Wörner, G., Kronz, A., 2002a. Minor and trace elements zoning in plagioclase: implications for magma chamber processes at Parinacota Volcano, northern Chile. Contributions to Mineralogy and Petrology 143, 300-315.

Ginibre, C., Kronz, A., Wörner, G., 2002b. High resolution quantitative imaging of plagioclase composition using accumulated backscattered electron images: new constraints on oscillatory zoning. Contributions to Mineralogy and Petrology 142, 436-448.

Ghiorso, M.S., Sack, R.O., 1995. Chemical mass transfer in magmatic processes 4. A revised and internally consistent thermodynamic model for the interpolation and extrapolation of liquid-solid equilibria in magmatic systems at elevated temperatures. Contributions to Mineralogy and Petrology 119, 197-212.

Gorbatov, A., Kostoglodov, K., Suarez, G., Gordeev, E., 1997. Seismicity and structure of the Kamchatka subduction zone. Journal of Geophysical Research 102, 17883-17898.

Gorbatov, A., Dominguez, J., Suarez, G., Kostoglodov, K., Zhao, D., Gordeev, E., 1999. Tomographic imaging of the P-wave velocity structure beneath the Kamchatka Peninsula. Geophysical Journal International 137, 269-279.

Grove, T.L., Baker, M.B., Kinzler, R.J., 1984. Coupled CaAl-NaSi diffusion in plagioclase feldspar: experiments and applications to cooling rate speedometry. Geochimica et Cosmochimica Acta 48, 2113-2121.

Hammer, J.E., Rutherford, M.J., 2002. An experimental study of the kinetics of decompression-induced crystallization in silicic melt. Journal of Geophysical Research 107, 1-24.

Higgins, M.D., 1996. Crystal size distributions and other quantitative textural measurements in lavas and tuff from Egmont Volcano (Mt. Taranaki), New Zealand. Bulletin of Volcanology 58, 194-204.

Holten, T., Jamveit, B., Meakin, P., 2000. Noise and oscillatory zoning in minerals. Geochimica et Cosmochimica Acta 64, 1893-1904

Humphreys, M.C.S., Blundy, J.D., Sparks, R.S.J., 2006. Magma evolution and opensystem processes at Shiveluch Volcano: insights from phenocrysts zoning. Journal of Petrology 47, 2303-2334.

Ivanov, B.V., Flerov, G.B., Masurenkov, Y.P., Kirianov, V.Y., Melekestsev, I.V., Taran, Y.A., Ovsiannikov, A.A., 1996. The 1991 eruption of Avacha Volcano: dynamics and composition of eruptive products. Journal of Volcanology and Seismology 17, 369-394.

Izbekov, P.E., Eichelberger, J.C., Patino, L.C., Vogel, T.A., Ivanov, B.V., 2002. Calcic core of plagioclase phenocrysts in andesite from Karymsky Volcano: evidence for rapid introduction by basaltic replenishment. Geology 30, 799-802.

Johannes, W., 1978. Melting of plagioclase in the system $\mathrm{Ab}-\mathrm{An}-\mathrm{H}_{2} \mathrm{O}$ at $\mathrm{P}_{\mathrm{H} 2 \mathrm{O}} \leq 5 \mathrm{kbars}$, an equilibrium problem. Contributions to Mineralogy and Petrology 66, 295-303.

Johannes, W., Koepke, J., Behrens, H., 1994. Partial melting reactions of plagioclase and plagioclase bearing systems. In: Parson, I. (Ed.), Feldspar and Their Reactions. Kluwer, Dordrecht, pp. 161-194.

L'Heureux, I., 1993. Oscillatory zoning in crystal growth: a constitutional undercooling mechanism. Physical Review E 48, 4460-4469.

Levin, V., Shapiro, N., Park, J., Ritzwoller, M., 2002. Seismic evidence for catastrophic slab loss beneath Kamchatka. Nature 418, 763-767.

Lofgren, G.E., 1980. Experimental studies on the dynamic crystallization of silicate melts. In: Hargraves, R.B. (Ed.), Physics of Magmatic Processes, chapter 11. Princeton University Press, Princeton, pp. 487-551.

Masurenkov, Yu.P., Egorova, I.A., Puzankov, M.Yu., et al., 1991. Avachinsky Volcano: Kamchatka active volcanoes (In Russian). In: Fedotov, S.A. (Ed.), Active Volcanoes of Kamchatka, vol. 2. Nauka, Moscow, pp. 246-273.

Melekestsev, I.V., Braitseva, O.A., Dvigalo, V.N., Bazanova, L.I., 1994a. Historical eruptions of the Avacha Volcano, Kamchatka. Attempt of modern interpretation and classification for long-term prediction of the types and parameters of future eruptions. Part 1 (1737-1909). Journal of Volcanology and Seismology 15, 649-666.

Melekestsev, I.V., Braitseva, O.A., Dvigalo, V.N., Bazanova, L.I., 1994b. Historical eruptions of the Avacha Volcano, Kamchatka. Attempt of modern interpretation and classification for long-term prediction of the types and parameters of future eruptions. Part 2 (1926-1991). Journal of Volcanology and Seismology 16, 93-114.

Melekestsev, I.V., Braitseva, O.A., Ponomareva, V.V., 1989. Prediction of volcanic hazards on the basis of the study of dynamics of volcanic activity in Kamchatka. Volcanic Hazards Assessment and Monitoring: IAVCEI Proceedings in Volcanology I. Springer-Verlag, Berlin/Tokyo, pp. 10-35.

Morimoto, M., 1988. Nomenclature of pyroxenes. Mineralogical Magazine 52, 535-550.

Nakamura, M., Shimakita, S., 1998. Dissolution origin and syn-entrapment compositional changes of melt inclusions in plagioclase. Earth and Planetary Science Letters $161,119-133$
Nelson, S.T., Montana, A., 1992. Sieve textured plagioclases in volcanic rocks produced by rapid decompression. American Mineralogist 77, 1242-1249.

Nicotra, E., Viccaro, M., in press. Unusual magma storage conditions at Mt. Etna (Southern Italy) as evidenced by plagioclase megacryst-bearing lavas: implications for the plumbing system geometry and summit caldera collapse. Bulletin of Volcanology, doi:10.1007/s00445-011-0566-9.

Ortoleva, P.J., 1990. Role of attachment kinetic feedback in the oscillatory zoning of crystal grown from melts. Earth Science Review 29, 3-8.

Papale, P., 1999. Modeling of the solubility of a two component $\mathrm{H}_{2} \mathrm{O}+\mathrm{CO}_{2}$ fluid in silicate liquids. American Mineralogist 84, 477-492.

Papale, P., Moretti, R., Barbato, D., 2006. The compositional dependence of the saturation surface of $\mathrm{H}_{2} \mathrm{O}+\mathrm{CO}_{2}$ fluids in silicate melts. Chemical Geology 229, 78-95.

Pearce, T.H., Kolisnik, A.M., 1990. Observation of plagioclase zoning using interference imaging. Earth Science Review 29, 9-26.

Pearce, T.H., Russel, J.K., Wolfson, I., 1987. Laser-interference and Nomarsky interference imaging of zoning profiles in plagioclase phenocrysts from the May 18, 1980, eruption of Mount St. Helens, Washington. American Mineralogist 72 1131-1143.

Pineau, F., Shilobreeva, S., Kadik, A., Javoy, M., 1998. Water solubility and D/H fractionation in the system basaltic andesite- $\mathrm{H}_{2} \mathrm{O}$ at $1250^{\circ} \mathrm{C}$ and between 0.5 and 3 kbars. Chemical Geology 147, 173-184.

Ponomareva, V.V., Melekestsev, I.V., Dirksen, O.V., 2006. Sector collapses and large landslides on Late Pleistocene-Holocene volcanoes in Kamchatka, Russia. Journal of Volcanology and Geothermal Research 158, 117-138.

Portnyagin, M.V., Manea, V.C., 2008. Mantle temperature control on composition of arc magmas along the Central Kamchatka Depression. Geology 36, 519-522.

Portnyagin, M.V., Mironov, N.L., Matveev, S.V., Plechov, P.Y., 2005. Petrology of avachites, high-magnesian basalts of Avachinsky Volcano, Kamchatka: II. Melt inclusions in olivine. Petrology 13, 322-351.

Portnyagin, M., Hoernle, K., Plechov, P., Mironov, N., Khubunaya, S., 2007. Constraints on mantle and composition and nature of slab components in volcanic arcs from volatiles $\left(\mathrm{H}_{2} \mathrm{O}, \mathrm{S}, \mathrm{Cl}, \mathrm{F}\right)$ and trace elements in melt inclusions from the Kamchatka Arc. Earth and Planetary Science Letters 255, 53-69.

Putirka, K., 2005. Igneous thermometers and barometers based on plagioclase + liquid equilibria: tests of some existing models and new calibrations. American Mineralogists $90,336-346$.

Puzankov, M.Yu., Bazanova, L.I., Maximov, A.P., Moskalyova, S.V., 2004. The initial Plinian basic andesite eruptions of the Young Cone, Avachinsky Volcano (Kamchatka). Linkages among tectonics, seismicity, magma genesis and eruption in volcanic arcs. IV International Biennal Workshop on subduction processes emphasizing the Japan-Kurile-Kamchatka-Aleutian arcs. Petropavlovsk-Kamchatsky, pp. 158-160. August 21-27,.

Ruprecht, P., Wörner, G., 2007. Variable regimes in magma systems documented in plagioclase zoning patterns: El Misti stratovolcano and Andahua monogenetic cones. Journal of Volcanology and Geothermal Research 165, 142-162.

Ruprecht, P., Bergantz, G.W., Dufek, J., 2008. Modeling of gas-driven magmatic overturn: tracking of phenocrysts dispersal and gathering during magma mixing. Geochemistry, Geophysics, Geosystems 9, Q07010.

Shcherbakov, V.D., Plechov, P.Yu., Izbekov, P.E., Shipman, J.S., 2011. Plagioclase zoning as an indicator of magma processes at Bezymianny Volcano, Kamchatka. Contributions to Mineralogy and Petrology 162, 83-99.

Singer, B.S., Dungan, M.A., Layne, G.D., 1995. Textures and Sr, Ba, Mg, Fe, K and Ti compositional profiles in volcanic plagioclase: clues to the dynamics of calcalkaline magma chamber. American Mineralogist 80, 776-798.

Smith, R.K., Lofgren, G.E., 1983. An analytical and experimental study of zoning in plagioclase. Lithos 16, 153-168.

Streck, M.J., 2008. Mineral textures and zoning as evidence for open system processes. In: Putirka, K.D., Tepley III, F.J. (Eds.), Minerals, Inclusions and Volcanic Processes. : Reviews in Mineralogy and Geochemistry, vol. 69. Mineralogical Society of America pp. 595-622.

Tolstykh, M.L., Badansky, A.D., Naumov, V.B., Bazanova, L.I., Kononkova, N.N., 2002. Chemical compositions, trace elements, and volatile components of melt inclusions in minerals from andesites of the Avachinskii Volcano, Kamchatka. Geochemistry International 40, 1112-1119.

Tsuchiyama, A., 1985. Dissolution kinetics of plagioclase in the melt of the system diopside-albite-anorthite and the origin of dusty plagioclase in andesites. Contributions to Mineralogy and Petrology 89, 1-16.

Tsuchiyama, A., Takahashi, E., 1983. Melting kinetics of a plagioclase feldspar. Contributions to Mineralogy and Petrology 84, 345-354.

Viccaro, M., Giacomoni, P.P., Ferlito, C., Cristofolini, R., 2010. Dynamics of magma supply at Mt. Etna Volcano (Southern Italy) as revealed by textural and compositional features of plagioclase phenocrysts. Lithos 116, 77-91.

Volynets, O.N., 1994. Geochemical types, petrology and genesis of late Cenozoic volcanic rocks from the Kurile-Kamchatka island-arc system. International Geology Review 36, 373-405.

Zavaritsky, A.N., 1977. Avacha Volcano in Kamchatka (In Russian). Nauka, Moscow, pp. 1-308. 